\title{
Climate change stressors and social-ecological factors mediating access to subsistence resources in Arctic Alaska
}

\author{
Kristen M. Green $^{1}$, Anne H. Beaudreau ${ }^{2,3}$, Maija H. Lukin ${ }^{4}$ and Larry B. Crowder ${ }^{5}$
}

\begin{abstract}
Human access routes to coastal subsistence resources are being altered in Arctic regions as temperatures warm. The accessibility dimension of climate impacts on coastal resources is critical to food sovereignty and resilience of Indigenous Arctic communities, yet the issue of access is understudied relative to food availability. This issue also has implications for the role of governmental agencies in mediating resource access in a changing landscape. We examined the role of climate stressors in affecting access to customary and traditional foods (subsistence) by Indigenous (Iñupiat) communities within and near Arctic National Parklands. We apply access theory to better understand (1) the climate stressors that most impact access to coastal animals and harvest areas, (2) how they affect the availability and reliability of harvest of coastal species, and (3) the mechanisms that facilitate or constrain access to coastal subsistence resources. Our study employed a combination of expert interviews and synthesis of pre-existing environmental time series data in the communities of Kotzebue and Kivalina, Alaska. We found that chronic climate stressors (sea ice retreat, coastal erosion, and changes in weather) most impacted harvest access. To mediate these changes, harvesters ubiquitously reported the use of access mechanisms including capital, knowledge, technology, and social identity; social relations, authority, and time were also reported at high rates. Potential adaptations in these communities include increased reliance on technology and capital to access animals despite landscape changes (e.g., using boats in the absence of sea ice), switching species or relying on social networks for sharing resources when animals become harder to find, and exploring alternatives to harvesting (such as growing food) in response to increasing access challenges. Our findings highlight the stewardship and sovereignty of Indigenous communities as a basis for resilience in a rapidly changing environment.
\end{abstract}

Key Words: adaptation; access theory; Arctic; climate change; Indigenous food sovereignty; subsistence; traditional ecological knowledge

\section{INTRODUCTION}

Hundreds of millions of people around the world depend on coastal resources for food, livelihoods, and culture (Berkes et al. 2001, Teh and Sumalia 2013, Seggel and De Young 2016). Global climate change has increased the pressure on marine and terrestrial species that use coastal areas through habitat loss, direct physiological changes, and ecosystem alteration (Brierley and Kingsford 2009, Pecl et al. 2017). Examples include loss of sea ice for ice-dependent marine mammals (Laidre et al. 2008, Huntington et al. 2016), poleward migrations of fish populations as waters warm (Morley et al. 2018), and coral bleaching from increased sea temperatures (Cinner et al. 2015). These changes can cause fluctuations in species' populations, migrations, and distribution patterns, and perpetuate cascading trophic effects on ecosystem function, all of which impact resource abundance (Brander 2010, Sumaila et al. 2011, Pecl et al. 2017). In addition to climate change effects on the distribution and abundance of biota, environmental change can also impact humans' ability to access coastal resources. Thus, even if resources are abundant, individuals cannot benefit from resources they cannot access.

Understanding how climate change disrupts access to resources and what mechanisms maintain access is important for facilitating adaptive capacity in coastal communities (Calderón-Contreras and White 2020), yet the issue of access is understudied relative to food availability (Schmidhuber and Tubiello 2007, PinstrupAndersen 2009). As climate change causes increased perturbations in coastal landscapes and weather (e.g., Post et al. 2019), this will change human access to resources, defined as the "ability to derive benefits from things" (Ribot and Peluso 2003:153). Climate change will potentially increase access for some individuals while excluding others. For example, in the Northwest Atlantic, large vessel fleets were able to adapt by following shifting fish distributions northward, while smaller vessel fleets were unable to persist over time because of their more limited mobility (Young et al. 2019). Similarly, in Arctic regions, sea ice retreat associated with climate change may require fishers to use boats rather than snow machines for transportation to fishing grounds as coastal waterways open, but a lack of financial resources may preclude some harvesters from switching to new technologies (this study). Few studies to date have examined how changing coastal environments, resulting from global climate change, affect Arctic resource access (Cold et al. 2020).

In Arctic regions, climate-related stressors like sea ice retreat, coastal erosion, and melting permafrost are re-sculpting land and seascapes, shifting patterns in animal migration and changing people's ability to reach animals overland or safely on sea ice (Pearce et al. 2010, Moerlein and Carothers 2012, Brinkman et al. 2016). Here, we examine how people's access to harvesting areas and wild foods for customary and traditional use is changing in coastal Indigenous (Iñupiat) communities of Arctic Alaska. In this region, communities are particularly reliant on coastal resources for subsistence needs (Moerlein and Carothers 2012, Cisneros-Montemayor et al. 2016, Huntington et al. 2020); for example, approximately $227 \mathrm{~kg}$ of wild foods are harvested per person annually $(25 \%-30 \%$ of food intake) in northwestern Alaska, USA (Magdanz et al. 2010, 2011). The ability for coastal

${ }^{1}$ Emmett Interdisciplinary Program in Environment and Resources, Stanford University, ${ }^{2}$ University of Alaska Fairbanks, College of Fisheries and Ocean Sciences, ${ }^{3}$ University of Washington, College of the Environment, School of Marine and Environmental Affairs (current affiliation), ${ }^{4}$ National Park Service (Western Arctic National Parklands), ${ }^{5}$ Hopkins Marine Station, Stanford University 
communities to access resources is being significantly affected by rapid and ongoing environmental change (Corell 2006, Brinkman et al. 2016). To better understand changes in access, associated responses of harvesters, and resiliency of local food systems, we ask, (1) What acute or chronic climate stressors most impact access to coastal resources? (2) How do they affect the availability of wild foods and reliability of hunting and harvesting? and (3) What factors facilitate or constrain access to coastal resources?

We apply access theory in relation to coastal resource use to identify the mechanisms that facilitate or constrain access in and around the Western Arctic National Parklands (WEAR), which are federally managed by the U.S. National Park Service (NPS). The NPS mission statement is unique among federal land management agencies in its intention to protect both "cultural and natural resources." Protection of cultural resources includes maintaining access to customary and traditional use of wild foods by Iñupiat who have resided in this region for time immemorial and who continue to practice land stewardship based on cultural knowledge (Burch 1998, Whiting et al. 2011, Topkok 2015). The concept of access is particularly relevant on federal parklands in the context of existing legislation intended to protect subsistence harvest. The Alaska National Interest Land Claims Act (ANILCA) of 1980 mandated access to subsistence resources on federal lands in Alaska. In ANILCA, and in other state and federal legislation, the term "subsistence" is defined on the basis of nutritional and material uses of wild renewable resources by rural residents, e.g., hunting and fishing for food or handicrafts (U.S. Congress 1980); however, this minimal view of subsistence does not capture the broader cultural, spiritual, and intergenerational traditions of Indigenous hunting and harvesting. In this paper, we use the term "subsistence" more holistically, to describe the intergenerational, land- and sea-based practices of harvesting and knowledge transfer embodied in Iñupiat ways of life.

Impacts of climate change on physical access to coastal species and harvesting areas are embedded within the political dimensions of harvest access, including issues of authority (Ribot and Peluso 2003). Food sovereignty, or "the right of peoples and governments to choose the way food is produced and consumed in order to respect ... livelihoods, as well as the policies that support this choice" (Via Campesina 2008:57), is an important facet of self-determination by Indigenous nations (Whyte 2018). Indigenous food sovereignty - a precondition for food security (ICC-Alaska 2015) - is also key to climate change resiliency. Therefore, understanding how rapid environmental change is altering access to customary and traditional use of wild foods ("subsistence") necessitates a broader conceptualization of access to include social, cultural, political, and economic dimensions.

Our primary theoretical contribution is to develop a novel and empirically grounded conceptual framework that we use to (1) document effects of climate-related shocks and stressors on harvesters' access to coastal resources, and (2) identify the social, cultural, political, and economic mechanisms that mediate access in the context of adaptive capacity (Fig. 1). We build on theoretical foundations of adaptive capacity literature, that is, the domains of learning and knowledge, diversity and flexibility, governance and institutions, natural capital, and access to assets that have been linked to adaptation in the coastal social-ecological literature (Bennett et al. 2014, Whitney et al. 2017, Green et al. 2021), but apply them through the lens of access theory, which has been established and empirically tested in many settings (Myers and Hansen 2020). To do so, we combine and ground our framework using data from semi-structured interviews and environmental datasets.

\section{THEORETICAL FRAMEWORK}

Ribot and Peluso (2003) developed a theoretical framework with which to dynamically map the processes and relationships that constrain or enable access to natural resources. This theory describes both the ways that access is controlled and maintained (Berry 1993) and establishes categories of the structural and relational access mechanisms that influence access within a given political-economic and cultural framework. Access theory has been traditionally applied with respect to land use and natural resources (Myers and Hansen 2020); here we expand this theory to a coastal social-ecological system with respect to climate adaptation. One of the values of access theory is that it can be used to help identify the social as well as material/property relationships that aid or exclude people in deriving benefits from natural resources. This is especially important to identify power inequities that are inherently linked to access (Sikor and Lund 2009), and exclusion from access of resources as communities respond to environmental changes (Calderón-Contreras and White 2020).

Fig. 1. Inductively derived conceptual framework for analysis of community responses to effects of climate stressors on harvest access, as well as the access mechanism that could influence the response (adapt, react, or cope) to that stressor. Climate stressors included sea ice loss, coastal erosion, weather changes, high water/flooding, snow cover, and permafrost degradation. Access mechanisms included authority, capital, knowledge, social identity, social relations, technology, and time.

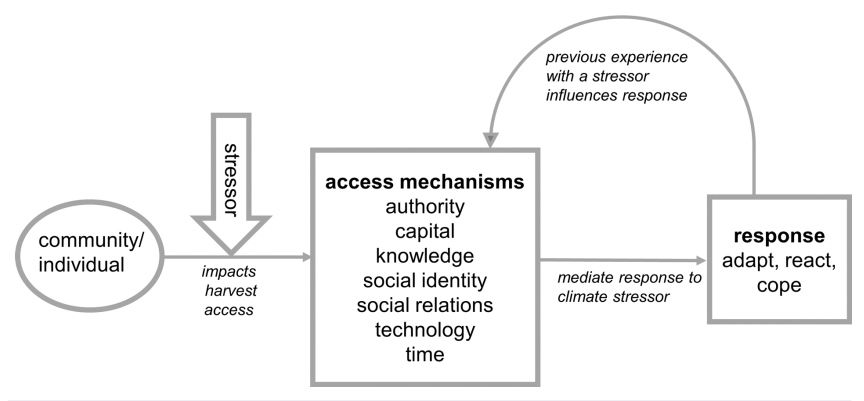

We combine access theory with an inductively derived conceptual framework to identify acute shocks (sudden, but time-limited) and chronic stressors (long-term trends not associated with a specific timeframe; Lazarus 2006, DFID 2011) that affect access to coastal subsistence resources. Using this framework, we examine how certain mechanisms of access (i.e., authority, knowledge, social relations, social identity, technology, capital) may mediate the adaptation response to stressors (Fig. 1). In addition, we add a new access mechanism (time), which we documented as mediating access to Arctic coastal resources. 


\section{METHODS}

\section{Case study location}

Our case study focuses on access to coastal subsistence resources in two northwestern Alaska communities (Kotzebue, population 3201 and Kivalina, population 374; U.S. Census 2010) near Cape Krusenstern National Monument (CAKR) within WEAR as well as a subsistence camp (Sisualik) near Kotzebue (Fig. 2). Approximately $80 \%$ of the population in the region is Alaska Native (predominantly Iñupiat; U.S. Census 2010). Residents are heavily reliant on marine resources and frequent coastal areas of CAKR for subsistence, social and cultural uses, and as a transportation corridor to other harvest locations. Kivalina is a remote community with limited infrastructure and is highly dependent on subsistence, while Kotzebue, the regional hub, has a mixed cash-subsistence economy with daily jet service and barge access. Today these are permanent residences, but historically people lived semi-nomadically and moved in harmony with the seasons to benefit from animal migrations and in accordance with cultural practices. Fish camps such as Sisualik, a seasonal camp 15 miles northwest from Kotzebue on Kotzebue Sound, are still used today with mostly Kotzebue and Noatak residents present in the summer for salmon and seal harvesting (Fig. 2). In addition to the climate-change related warming in the region described above, past threats to food sovereignty and security in this region have included the overexploitation of Arctic marine mammals (mid-1800s; Burch 1975) and non-native settler contact (early 1800s; Burch 1998). Settler colonialism hastened the spread of disease and alcoholism (Lepóla 2010) and religious missionaries aimed to convert Alaskan Natives to Christianity. Mineral resource exploration since the 1970s has altered the physical landscape and disrupted animal migrations, while increasing environmental contamination (Kerin and Lin 2010). Still, the people of the region pursue collective continuance, or resiliency to both colonialism and climate change, through cultural, economic, political, and social sovereignty and well-being (Whyte 2018, Griffin 2019).

We speculated that the distinct characteristics of these two coastal communities may affect harvest accessibility and thus were interested in comparing access changes between them. Subsistence harvesters in the region access marine resources on Kotzebue Sound, through brackish lagoon and river systems, and on the coast of the Chukchi Sea. Marine resources account for $80 \%$ of subsistence harvest in Kivalina (Magdanz et al. 2010) and $57 \%$ in Kotzebue (Braem et al. 2017). Primary marine species harvested are bearded seal (Erignathus barbatus), salmon (Oncorhynchus spp.; primarily chum salmon, O. keta), and whitefishes (Coregoninae; Braem et al. 2017). Although the current geopolitical landscape is a complex mix of private, state, and federal lands with overlapping regulatory jurisdictions, Indigenous peoples have lived in this area for millennia and have a sustained connection with the land.

\section{Interview protocol}

To develop our research design and protocol, we worked closely with community members to design specific objectives in conjunction with tribal guidance and community needs (Kovach 2010, Lewis and Boyd 2013). We met with the research coordinator for the Native Village of Kotzebue (tribal government) and Alaska Native community leaders. Together we
Fig. 2. Study area in Northwest Arctic with National Parkland boundaries (Bering Land Bridge National Preserve (BELA), Cape Krusenstern National Monument (CAKR), and Noatak National Preserve (NOAT). Erosion areas (red polygons) are areas that subsistence harvesters reported during interviews: Area 1, Kiligmak Lagoon North of Cape Krusenstern $(n=1)$; Area 2, Cape Krusenstern $(n=2)$; Area 3, Anigak/Auklak Lagoon $(n=8)$; Area 4, Sisualik Spit $(n=4)$; Area 5, Sadie Creek $(n=2)$; Area 6, Cape Blossom south to Arctic Circle (n $=7$ ). Important ecological subsistence areas values are derived from Iñuniałiqput Ilịlugu Nunayyuanun (Documenting our way of life through maps; Sattherwaite-Phillips et al. 2016) and based on summation of reproduction, rearing, feeding, migration, or general health for the following groupings: subsistence harvesters, birds, fish, marine mammals, sea ice, benthic species, and primary production; that is, an area important for reproduction and feeding would receive a value of 2, while an area only important for reproduction would receive a value of 1 .

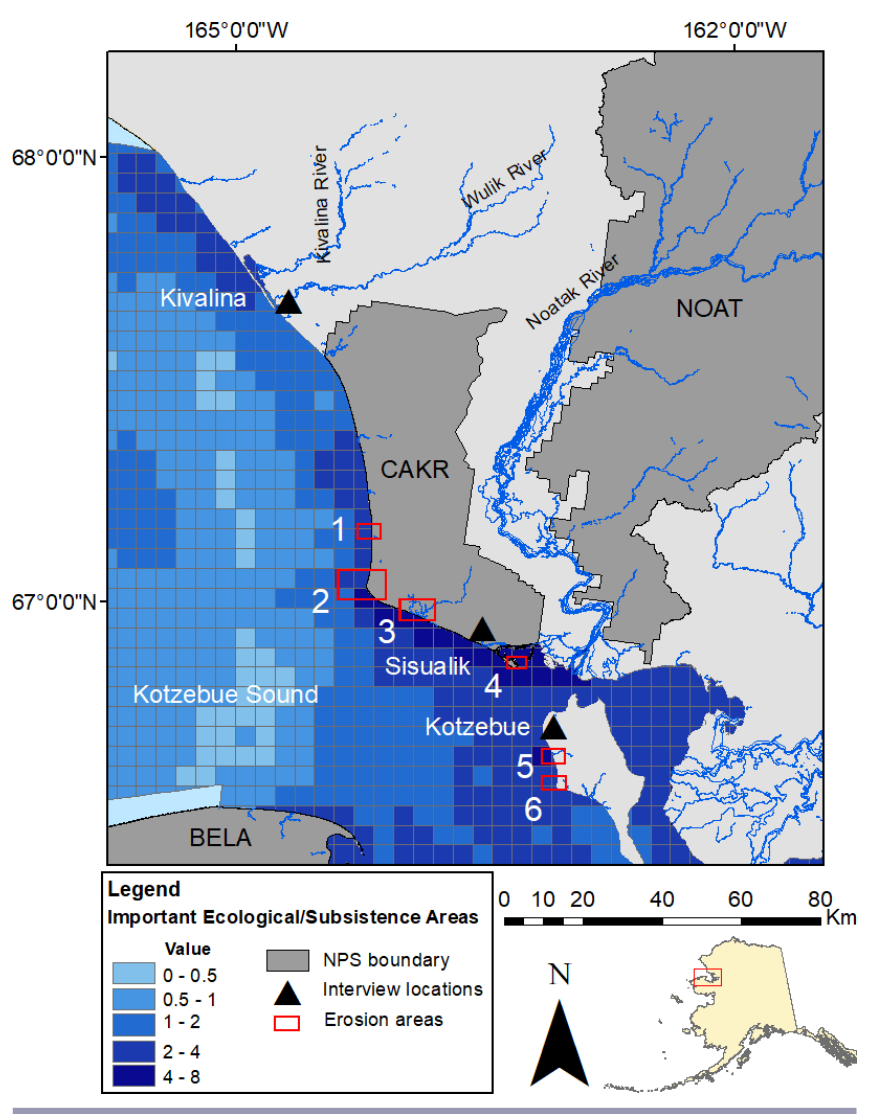

developed a semi-structured interview protocol (Bernard 1988) and established compensation rates for research participants, following principles for conducting research in the Arctic (IARPC 2018). Community leaders also connected us with prospective research participants. Additional participants in all communities were identified through stratified chain referral, or snowball sampling (Bernard 2006). The study design and interview protocol were approved by the Native Village of Kotzebue and the Native Village of Kivalina, as well as Institutional Review 
Table 1. Sample size of interviewees by participant group and percentage of each participant group that mentioned an environmental access challenge. Couple and group interviews were counted by the individuals present.

\begin{tabular}{|c|c|c|c|c|c|c|c|c|}
\hline Participant Group & $\begin{array}{c}\text { Number } \\
\text { participants }\end{array}$ & Sea Ice $(\%)$ & Weather $(\%)$ & $\begin{array}{c}\text { Coastal } \\
\text { Erosion }(\%)\end{array}$ & High Water (\%) & $\begin{array}{c}\text { Snow } \\
\text { Cover }(\%)\end{array}$ & Permafrost (\%) & $\begin{array}{c}\text { Climate } \\
\text { Change }(\%)\end{array}$ \\
\hline \multicolumn{9}{|l|}{ Interview type } \\
\hline $\begin{array}{l}\text { Subsistence } \\
\text { harvesters (all) }\end{array}$ & 59 & 69 & 50 & 17 & 10 & 10 & 7 & 5 \\
\hline $\begin{array}{l}\text { Subsistence } \\
\text { harvesters } \\
\text { (Kotzebue) }\end{array}$ & 47 & 77 & 57 & 23 & 13 & 13 & 10 & 0 \\
\hline $\begin{array}{l}\text { Subsistence } \\
\text { harvesters } \\
\text { (Kivalina) }\end{array}$ & 12 & 50 & 33 & 0 & 0 & 0 & 0 & 17 \\
\hline
\end{tabular}

Boards at Stanford University and University of Alaska Fairbanks.

We sought to interview participants who identified as subsistence harvesters (over 18 years of age) in Kotzebue, Kivalina, and Sisualik and who were experienced with harvesting or processing subsistence foods. We aimed to interview people across multiple age groups and genders to gain diverse perspectives on climatic stressors/shocks and changes in access to harvest. The majority of interviews were conducted with individuals, although we conducted several interviews with couples or small groups, depending on the comfort level of the participants. Interviews were held between June 2017 and July 2019. Most interviews were conducted by the first and second authors together, although some were completed by the lead author alone. During interviews, we asked questions related to factors affecting access to coastal resources, changes in animal availability and seasonal harvest timing, and current or anticipated future responses of harvesters to challenges in harvest access (Appendix 1). We recruited interview participants until we had reached data saturation, that is, no new codes or themes were being generated through additional interviews (Guest et al. 2006, Saunders et al. 2018).

\section{Interview analysis}

Interviews were recorded with participant permission and transcribed in full. Transcribed interviews were imported to NVivo Software (QSR International 2011). The lead author coded all interviews and reviewed sections of coded interviews with the second author to refine and calibrate codes, and to discuss preliminary themes and interpretations. We first used thematic analysis (Braun and Clarke 2006) to identify dominant and repeated themes in the interviews related to climate-related shocks/stressors impacting harvest access, seasonal changes in harvest of animals, and examples of adaptation to change. We anticipated that climate change in the Arctic would result in both acute shocks and chronic stressors and coded for both types. We defined changes in harvest access as the temporal or spatial elimination, creation, enhancement, or disruption of land/sea routes to access resources because of physical mechanisms. We then deductively coded the interviews to document specific access mechanisms drawn from access theory that mediate (facilitate or constrain) harvesters' access to coastal subsistence resources. We triangulated the results from interviews with notes from participant observations (Flick et al. 2004) at community potlucks, fishing for salmon and sheefish, and visiting seasonal subsistence camps, as well as analyses of trends in key stressors from environmental time series.

\section{Environmental data summary}

We complemented observations about climate stressors from interview data with quantitative environmental data to assess trends and timing of stressors. We sought to triangulate our interview results with these data summaries to increase the validity of our data through multiple methodological approaches (Denzin 2009) and examine whether harvester perceptions of environmental change matched externally collected data. Based on the thematic analysis of interviews, we selected the most frequent climatic stressors that participants identified as impacting harvest or access to harvest, i.e., sea ice extent, weather, and coastal erosion. We then reviewed recent literature for regional trends in sea ice (Farquharson et al. 2018) and erosion (Gibbs et al. 2019) and summarized publicly available data for air temperature as a proxy for weather changes to characterize major trends over time and compare these to local harvester observations (Appendix 2). Mean air temperatures were calculated as the average of daily temperature values for each month and year (1998-2020) using the NOAA National Center for Environmental Information Climate Data online database (https://www.ncdc.noaa.gov/cdo-web/) for Kotzebue and Kivalina; time periods were selected to correspond with harvesters' observations of change. To estimate changes in temperature over the 1998 to 2020 period, we fitted linear regression models to time series of mean temperature values, separately for each month and region.

\section{RESULTS}

Between June 2017 and July 2019, we completed 50 individual, two couple, and two group interviews with a total of 59 experts from Kivalina and Kotzebue (Table 1), which met the sampling and saturation goals noted above. Twenty-four participants identified as female and 35 as male; 9 were 19-29 years of age, 18 were $30-49,22$ were $50-69$, and 10 were 70-89; and 58 identified as Alaska Native or Alaska Native and another race and two identified as Caucasian. Below, we report results from the thematic analysis of these interviews, which were also informed by participant observations, in four sections: climate stressors affecting harvest access, climate stressor impacts on the seasonality or availability of coastal subsistence harvest, mechanisms that mediate access to coastal subsistence resources, and potential adaptation measures of harvesters to change. 
Results are given as the percentage of participants who reported each stressor and access mechanism. In each of these sub-sections, we compare and contrast harvester data from Kotzebue and Kivalina. Environmental data summaries provided additional context for interpretation of harvester observations of landscape changes.

\section{Climate stressors affecting harvest access}

Harvesters were asked to describe the stressor or stressors that had the greatest effect on their access to coastal subsistence resources, i.e., change in time or distance to access species, or decision to harvest at all. Most harvesters reported more than one type of climate stressor that affected harvesting, but the climate stressors we documented were all chronic in nature; no acute shocks were reported. Changes in sea ice $(77 \%$ of Kotzebue participants; $50 \%$ Kivalina), weather (i.e., wind, precipitation as rain and snow, snow thickness and cover, air temperature; $57 \%$ Kotzebue; 33\% Kivalina), coastal erosion (23\% Kotzebue; $0 \%$ Kivalina), high water or flooding (13\% Kotzebue; $0 \%$ Kivalina), snow cover on the ground (13\% Kotzebue; $0 \%$ Kivalina), and permafrost degradation ( $13 \%$ Kotzebue; $0 \%$ Kivalina) were the prominent themes (Table 1; Appendix 3). Eleven harvesters reported only non-environmental stressors (i.e., fuel) and one harvester reported no stressors, environmental or otherwise. The range of stressors reported by Kotzebue harvesters was $0-5$ stressors (mean 1.9 stressors) and 1-2 stressors in Kivalina (mean 1.5 stressors) (Appendix 3). Even those individuals who had not identified specific stressors as affecting harvest access had noted environmental changes, particularly with respect to sea ice, at some point during the interview. Only Kivalina harvesters used the term "climate change" as a comprehensive category affecting access (17\% of participants; Table 1). Participants in both Kivalina and Kotzebue most commonly mentioned the late 2000s as the period when they began to experience changes in climate that affected access to coastal subsistence resources. We describe the three most frequent climate stressors affecting harvest access according to harvesters and the historical environmental trends documented for each in the region.

\section{Sea ice}

Our environmental data summaries indicated that sea ice for southern Chukchi Sea and Kotzebue Sound historically formed in October and persisted until June allowing 4-5 months of open water (Farquharson et al. 2018). However, "freeze up" in the fall has been getting later and the "break up" in the spring has been getting earlier, resulting in a decrease of ice-free seas by 7-10 days per decade since 1980 (Mahoney et al. 2014, Farquharson et al. 2018). Sea ice thickness in the region has also declined over a similar time frame (Maslanik et al. 2007). These trends in regional sea ice extent and sea ice thickness align with harvesters' perceptions; however, while the environmental data summaries indicate that changes in sea ice extent and thickness began in the 1980 s, harvesters reported noticing changes in the early 2000s, likely when these trends began to meaningfully impact their harvesting and traveling. Harvesters described several types of changes related to sea ice. These included traveling further to get to animals when the sea ice retreats quickly, or being unable to access animals at all because of unsafe (thin or rotten) ice conditions. For example, one harvester explained,
The quality of ice has deteriorated... I've heard a lot of hunters say that they've gone out and shot their seal, but they can't get to them because of the ... badice. Or they'd see one, but they wouldn't shoot it because of the bad ice, the quality of ice (male Kotzebue harvester, 40-44 years of age).

In addition to having to travel farther, over potentially unsafe ice to access ice-dependent animals like seals, the temporal window of availability for harvesting certain species has changed as a result of ice conditions, particularly for bearded seal (uugruk), which are typically harvested at the sea ice/open water transition zone. Another participant described this, saying that,

The ice is ... still here, but it doesn't stay here as long, so you've got like a two-week window to go and get them now... You just have to be more careful and a little bit more conservative and try to make the right choices (male Kotzebue harvester, 40-44 years of age).

\section{Coastal erosion}

Shoreline change data for the region shows a mix of accretion and erosion (Gibbs et al. 2019). In Kotzebue, overall rates of shoreline change were primarily erosional (Fig. 2; Gibbs et al. 2019). In Kivalina, overall shoreline rates were primarily accretional, with erosion "hotspots" along the shoreline (Gibbs et al. 2019). These data summaries aligned with harvester perceptions, in that only Kotzebue interviewees reported coastal erosion as negatively affecting travel to access harvest. In Kivalina, where accretion was greater than erosion, especially in harvesting areas, interviewees did not mention erosion as a problem specifically affecting access to harvest. Yet, the broader impacts of erosion along Kivalina's coastline are clear; a 2003 report identified Kivalina as one of several Alaska villages that are "in imminent danger from flooding and erosion and are making plans to relocate" (GAO 2003:3).

Erosion was reported by Kotzebue harvesters in six areas between Cape Blossom and Cape Krusenstern (24 mentions; Fig. 2); these erosion areas overlapped with documented areas of erosion (-1 to -3 meters/year) based on Gibbs et al. (2019). In addition to constraining travel, another access problem described by harvesters was damage or loss of property on Alaska Native allotments that are used for fishing or hunting camps due to erosion:

Coastal erosion up where I'm at is significant acreage, 30 miles north of Kotzebue. I'd say over the last 10 years, it's probably, I'd say, upwards of 10 acres in our area has literally washed away (male Kotzebue harvester, 70-74 years of age).

Erosion can also cause difficulty in accessing certain parts of the coastline along the beach during certain seasons:

We're seeing a lot of land erosion. Years ago we could go all the way to Arctic Circle with four wheelers along the beach. Nowadays you can't even do that. There ain't no more ground (male Kotzebue harvester, 35-39 years of age). 


\section{Weather}

Changes in the weather was the third most frequent stressor mentioned by harvesters. Harvesters described a variety of weather changes, including decreased snow cover, increased rain, increased storm intensity/frequency, and changes in wind direction and speed. Although long-term regional quantitative data were not available for all of these weather descriptors, our environmental data review indicated that temperatures in the region have tended to increase. Monthly temperature means for both Kotzebue and Kivalina show increasing trends overall, with greatest rates of increase in April, May, and October for both locations (Fig. A2.1, A2.2, Table A2.2). Depending on the month, mean Kotzebue air temperatures increased from 0.08 to $0.20^{\circ} \mathrm{C}$ per year and Kivalina temperatures increased from 0.05 to $0.35^{\circ}$ $\mathrm{C}$ per year (Table A2.2). Although weather is inherently variable in the region, these long-term increases in air temperatures, which are particularly significant around freeze up and break up periods in the fall and spring, likely underlie harvesters' experience of increasing unpredictably in weather forecasting and not being able to rely on historical weather patterns. A Kivalina hunter described the challenges this poses to planning harvesting activities, saying,

You can't predict anything anymore... our hunters used to just plan their day. As soon as they get up, go outside, look at the weather, look at the horizon, know what the day is going to be like and then go. But now people go out hunting, it looks okay and then, suddenly, they get hit with a storm (female Kivalina harvester, 60-64 years of age).

\section{Stressor impacts on the seasonality or availability of coastal subsistence harvest}

We asked participants about the coastal species they harvest, whether the seasonal timing of harvesting has changed and why, and over what approximate period they noticed these changes. We found that climate stressors, primarily sea ice changes, impacted the seasonality and availability of some of the species that harvesters regularly relied on for food, while stability in harvest of other species persisted despite climate stressors. In Kotzebue, of the 41 coastal species people described harvesting, harvests of three species were reported to have shifted several weeks earlier in the year: bearded seal (harvest begins in early May instead of late May), beluga (Delphinapterus leucas; harvest begins in late May instead of early June), and chum salmon (harvest begins in mid-June instead of early July; Fig. 3). Bearded seal and beluga were also described as having a truncated harvest period, thus overall creating a more time-limited harvest opportunity for both species. This period was up to a month shorter for bearded seal, ending at the beginning of July instead of the end of July and three weeks for beluga, ending in early to mid-July instead of the end of July. Beluga was also described as being harder to catch than in the past because of population declines in Kotzebue Sound that harvesters attributed to various sources, including the presence of killer whales (Orcinus orca), avoidance of the region because of engine noise (boat and jet plane), and an iceentrapment event in Russian waters. In addition, for bearded seal, increased unpredictability in sea ice break up and general weather patterns can result in fewer individual harvest days even within the contemporary (shorter) harvest season (Alex Whiting, Environmental Program Director for the Native Village of
Kotzebue, personal communication). In Kivalina, of 35 coastal species reported, we saw similar trends of early harvest for bearded seal (harvest begins in late April instead of early June, ending at the beginning of July rather than mid-July) and salmon (harvest begins five weeks early, in late May instead of early July). Unlike in Kotzebue, beluga harvest does not begin earlier, but ends two to three weeks sooner in July than in the past. These changes were described by harvesters as correlated with sea ice breaking up earlier in the spring.

Although only a portion of the harvesters' overall food portfolio changed in association with climate stressors, the effects were concentrated among species that harvesters rely on most for food security. In Kotzebue, either caribou (Rangifer tarandus granti) or bearded seal was identified as among the highest priority species for most harvesters ( $>90 \%$ ), however, people also noted the importance of fishes (sheefish, salmon) and moose. In Kivalina, $100 \%$ of harvesters reported either caribou or bearded seal as central to their subsistence harvest, however, they tended to describe other marine species like whales and fishes as equally important to caribou and seals more often than Kotzebue respondents. In addition to these observed shifts in earlier seasonal timing in harvest, experts reported that processing of these critical animals was affected by climate stressors. For example, processing and storing bearded seal in the absence of sea ice without meat spoiling is more difficult:

There is no ice to put [bearded seal] on to get them ready to put ... in the boat. Two weeks ago we got a bearded seal 10 miles out, and we couldn't harvest the inside because already spoiled before we even got to the beach (male Kivalina harvester, 40-44 years of age).

Further, earlier harvesting in the spring for bearded seal can mean colder weather, so the drying of seal meat and rendering of seal fat into oil can be negatively affected:

A lot of families had to bring their meat inside, or get fans or rig up a lot of things to get it to dry. 'Cause a lot of people's meat was rotting because it wasn't drying. A lot of people's oil was not rendering the way it normally does ... because it was so cold and chilly out (female Kotzebue harvester, 20-24 years of age).

These examples of changes in weather, or sea ice, meant that harvesters spent more time processing or developing solutions to process meat under unusual conditions, or that their harvest yields were less because of spoilage.

Mechanisms that mediate access to coastal subsistence resources We documented access mechanisms that enable both Kotzebue and Kivalina harvesters to continue to derive benefits from coastal resources in spite of environmental changes that affect the accessibility and availability of important species (Table 2). From our analysis of interviews, we identified capital, technology, social identity, and knowledge as the primary mechanisms mediating access to subsistence ( $>95 \%$ of harvesters in both Kotzebue and Kivalina). Social relations (89\% Kotzebue; $67 \%$ Kivalina), authority ( $53 \%$ Kotzebue; $58 \%$ Kivalina), or time (57\% Kotzebue; $83 \%$ Kivalina) were also important in mediating access. Further divisions of these access mechanisms into detailed sub-categories are found in Table 3; the most salient sub-categories are highlighted below. 
Fig. 3. Seasonal changes in the harvest of coastal plants and animals in Northwest Arctic Alaska from subsistence harvester interviews in Kotzebue, Alaska, in response to the question, "What months do you harvest coastal species now, and has that changed from the past?" Illustration by Cecil Howell and used with permission.

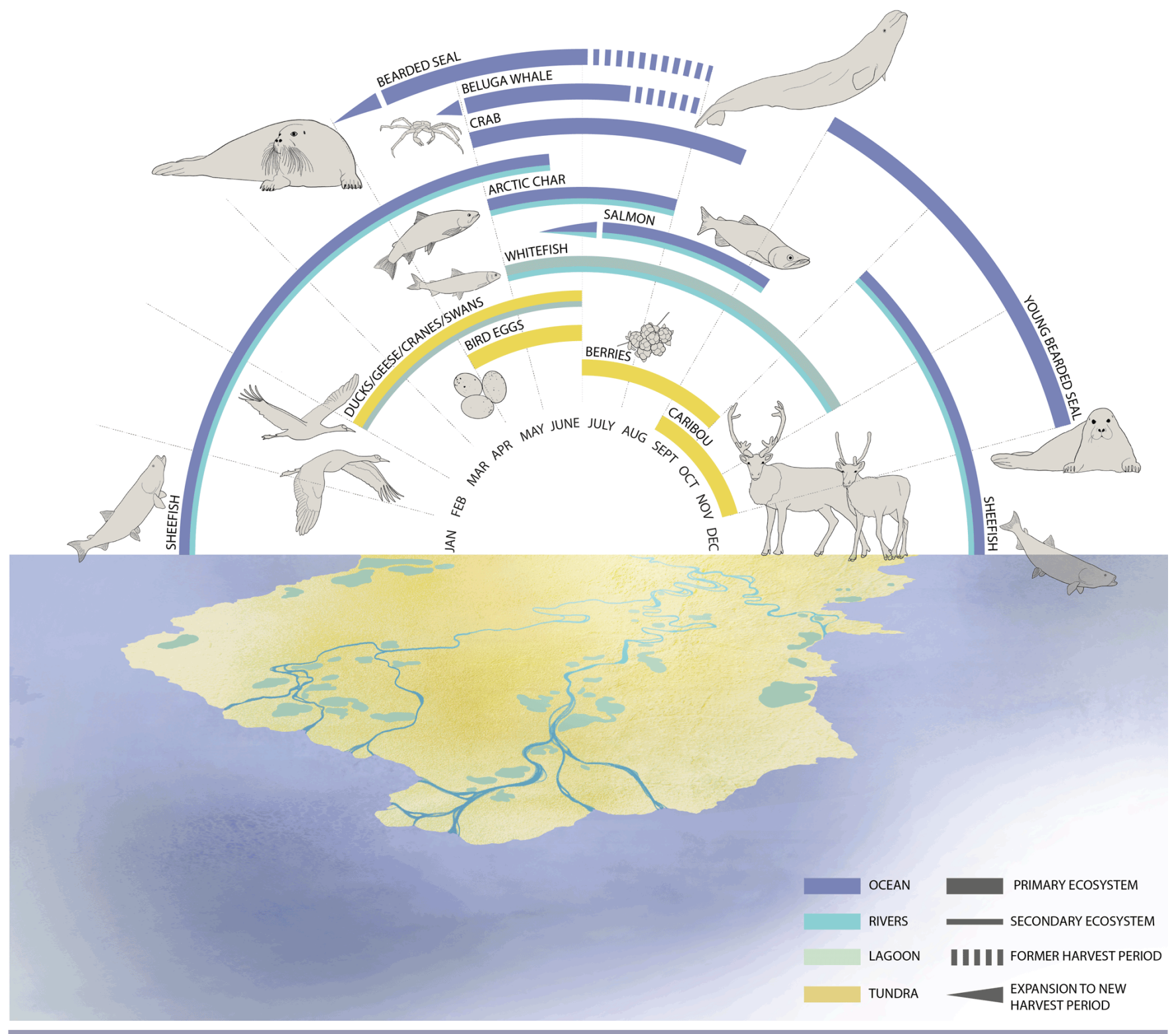

\section{Capital}

When access to animals under certain environmental conditions becomes more unpredictable, having access to multiple modes of transportation provides more opportunity to harvest animals whether the land and sea are frozen (snow machines) or there is open water and lack of snow on land (boat/ATV). Some harvesters own all three major modes of transportation (boats, ATVs, snow machines), but $100 \%$ of harvesters interviewed in both Kotzebue and Kivalina used at least two of the three modes whether they owned, borrowed, or traveled with others who owned vehicles. Sub-categories of capital, such as access to fuel were described as increasingly important as conditions become more unpredictable or harvesters travel longer to get to areas where there is sea ice to hunt bearded seal, for example. Owning an allotment (land deeded to Alaska Natives through the Alaska Native Allotment Act) may be viewed as a form of capital that preserves permanent access to harvest locations by Kotzebue harvesters (Table 3 ).

\section{Technology}

Access to technology was closely linked to capital, especially in the form of transportation, mentioned by all interviewed Kivalina and Kotzebue harvesters. As climate stressors, e.g., sea ice retreat, becomes increasingly common, the possession of modernized larger boats will allow people to access ocean resources more easily. Harvesters in Kotzebue mentioned using the internet as a 
Table 2. Access mechanism definitions (Ribot and Peluso 2003), examples from subsistence harvester interview data, and illustrative quotes from subsistence harvester interviews.

\begin{tabular}{|c|c|c|c|c|c|c|c|}
\hline $\begin{array}{l}\text { Access } \\
\text { Mechanism }\end{array}$ & Capital & Knowledge & Authority & Technology & Social Identity & Social Relations & Time \\
\hline Definition & $\begin{array}{l}\text { Wealth (finances and } \\
\text { equipment) used to } \\
\text { extract resources. } \\
\text { Access control } \\
\text { through the purchase } \\
\text { of rights. }\end{array}$ & $\begin{array}{l}\text { Beliefs, ideology, } \\
\text { negotiated } \\
\text { systems of } \\
\text { meaning, } \\
\text { technical skills, } \\
\text { and specialized } \\
\text { knowledge } \\
\text { influence ability } \\
\text { and cultural } \\
\text { norms in access. }\end{array}$ & $\begin{array}{l}\text { Privileged access to } \\
\text { individuals or } \\
\text { institutions with } \\
\text { authority to make } \\
\text { and implement } \\
\text { laws, individuals } \\
\text { can take advantage } \\
\text { of social identities } \\
\text { to acquire } \\
\text { resources. }\end{array}$ & $\begin{array}{l}\text { Many resources } \\
\text { cannot be } \\
\text { extracted with- } \\
\text { out the use of } \\
\text { tools or } \\
\text { technology. }\end{array}$ & $\begin{array}{l}\text { Social identity in } \\
\text { a community } \\
\text { including age, } \\
\text { gender, ethnicity, } \\
\text { religion, status, } \\
\text { profession, place } \\
\text { of birth, } \\
\text { common } \\
\text { education, etc. }\end{array}$ & $\begin{array}{l}\text { Negotiation of } \\
\text { other social } \\
\text { relations of } \\
\text { friendship, trust, } \\
\text { reciprocity, } \\
\text { patronage, } \\
\text { dependence, and } \\
\text { obligation. }\end{array}$ & $\begin{array}{l}\text { Cultural acceptance } \\
\text { of time away from } \\
\text { work to subsistence } \\
\text { harvest, commitment } \\
\text { to subsistence } \\
\text { harvesting that } \\
\text { prioritizes/is patient } \\
\text { for timing harvest } \\
\text { when the weather is } \\
\text { optimal. }\end{array}$ \\
\hline Example & Gasoline & $\begin{array}{l}\text { Family } \\
\text { knowledge } \\
\text { about harvesting }\end{array}$ & $\begin{array}{l}\text { User conflict over } \\
\text { caribou harvesting }\end{array}$ & $\begin{array}{l}\text { Transportation } \\
\text { technology } \\
\text { (boats, ATVs, } \\
\text { snow machine) }\end{array}$ & $\begin{array}{l}\text { Identity as an } \\
\text { Indigenous } \\
\text { harvester }\end{array}$ & $\begin{array}{l}\text { Sharing harvest } \\
\text { with friends and } \\
\text { family }\end{array}$ & $\begin{array}{l}\text { Having time away } \\
\text { from work to } \\
\text { subsistence harvest }\end{array}$ \\
\hline Quote & $\begin{array}{l}\text { The cost of gas and } \\
\text { cost of living around } \\
\text { here, it's so high. } \\
\text { (male, } 56 y \text { ) }\end{array}$ & $\begin{array}{l}\text { I start going out } \\
\text { with my dad and } \\
\text { my brother when } \\
\text { I was young, } \\
\text { before I could } \\
\text { even shoot a gun. } \\
\text { That's where we } \\
\text { learned to hunt. } \\
\text { Just watch and } \\
\text { learn. (male, } 52 \\
\text { y) }\end{array}$ & $\begin{array}{l}\text { There's been a lot } \\
\text { of...discussion on } \\
\text { whether or not to } \\
\text { close certain hunting } \\
\text { seasons. And then } \\
\text { whether it's fair to } \\
\text { close them to sport } \\
\text { users, or to sport } \\
\text { hunters and } \\
\text { subsistence users... } \\
\text { And who has more } \\
\text { right to it. } \\
\text { (female, } 21 \text { y) }\end{array}$ & $\begin{array}{l}\text { [We] don't own } \\
\text { a boat...we have } \\
\text { to borrow a boat, } \\
\text { or get a ride with } \\
\text { somebody that's } \\
\text { going. (female, } \\
55 \text { years) }\end{array}$ & $\begin{array}{l}\text { I've been really } \\
\text { lucky with my } \\
\text { traditional } \\
\text { hunting areas } \\
\text { that my } \\
\text { grandparents and } \\
\text { parents } \\
\text { selected... So } \\
\text { we're situated in } \\
\text { some prime } \\
\text { caribou crossing } \\
\text { areas. (female, } \\
37 \text { y) }\end{array}$ & $\begin{array}{l}\text { I had } 15 \text { gallons } \\
\text { of extra seal } \\
\text { [oil], send it to } \\
\text { these folks. They } \\
\text { share it with the } \\
\text { other folks. And } \\
\text { so that's how we } \\
\text { still do it. (male, } \\
65 \text { y) }\end{array}$ & $\begin{array}{l}\text { Time is a big deal. } \\
\text { And you're working. } \\
\text { Man, it's going to } \\
\text { limit your subsistence } \\
\text { activities because you } \\
\text { get done with work at } \\
\text { 5:00, and you're like, } \\
\text { Should I set a salmon } \\
\text { net? } \\
\text { (male, } 46 \text { y) }\end{array}$ \\
\hline
\end{tabular}

means of sea ice information and social media, e.g., Facebook, as a tool for learning about harvesting locations and animal abundance (Table 3). Kivalina harvesters did not describe using the internet as a means of sea ice information, although one harvester did mention access to social media to view other community members' comments about recent harvesting locations.

\section{Knowledge}

Knowledge shapes who can benefit from resources in northwest Arctic Alaska. All Kotzebue and Kivalina harvesters described learning from elders and family members about where to hunt which animals in which season; how to operate a boat, snow machine, or ATV; or how to aim and fire a rifle. This knowledge included Indigenous practices of how to track, hunt, process, and share harvest in conjunction with spiritual and cultural beliefs. Thirty-six percent of Kotzebue harvesters and 33\% of Kivalina harvesters described knowledge specific to sea ice safety as an important component of general harvesting knowledge. Thirty percent of Kotzebue harvesters and one Kivalina harvester described using social media as a source of harvesting knowledge, which they use to determine locations where others have recently been successful at harvesting, ask questions about processing techniques, and reduce time spent searching for plants and animals.

\section{Other mechanisms}

Other mediating mechanisms described were social identity, social relations, authority, and time. All Alaska Native Kivalina and Kotzebue harvesters stated that their identity as an Alaska Native allows access to hunting marine mammals for subsistence under the Marine Mammal Protection Act of 1972 (Table 3). In addition, Alaska Native cultural identity and ancestral whaling rights motivate some harvesters to continue an annual hunt for whales despite rarely catching these animals. Social relations are a critical, non-monetary means of sharing and accessing harvest resources in the northwest Arctic region of Alaska. Sharing of food and other resources is an important cultural value in Iñupiaq culture; most Kotzebue and Kivalina harvesters describe sharing harvest of plants and animals with others who lacked access to hunting technology, knowledge, or ability (Table 3). This sharing represents a critical network in the community (often strongest with immediate and extended family members) but also persists throughout the community. Social relations were also used to share costs in harvesting, e.g., transportation, gas, or other hunting equipment, by some Kotzebue and Kivalina harvesters (Table 3).

Authority, or access to the individuals or institutions with the authority to make and implement laws, can influence access for harvesters. Regulations that are more liberal (higher harvest limit, more flexible seasons and areas for harvesting) can facilitate access, as can the prioritization of subsistence through laws and regulations. For example, a common concern among Kotzebue and Kivalina was the negative effect of recreational harvesters traveling from outside the region to hunt caribou in traditional harvest areas (Table 3). Further inequities with the mechanism of authority exemplify how current power structures delimit Indigenous sovereignty: 
Table 3. Access mechanisms and sub-mechanisms reported to influence access to harvest by number and percentage of subsistence harvesters in Kotzebue and Kivalina. Major access mechanism categories were reported present if any of the sub-mechanisms were reported. Individual responses were tallied from group and couple interviews.

\begin{tabular}{|c|c|c|c|c|}
\hline \multirow{2}{*}{$\begin{array}{l}\text { Access mechanism and sub-group } \\
\text { Subsistence harvesters reporting }\end{array}$} & \multicolumn{2}{|c|}{ Kotzebue } & \multicolumn{2}{|c|}{ Kivalina } \\
\hline & $\#$ & $\%$ & \# & $\%$ \\
\hline Capital & 47 & 100 & 12 & 100 \\
\hline Transportation & 47 & 100 & 12 & 100 \\
\hline Allotment & 24 & 51 & 0 & 0 \\
\hline Fuel & 16 & 34 & 3 & 25 \\
\hline Hunting equipment & 4 & 9 & 0 & 0 \\
\hline Other (permit cost) & 1 & 2 & 0 & 0 \\
\hline Social Identity & 46 & 95 & 12 & 100 \\
\hline Hunting marine mammals & 46 & 95 & 12 & 100 \\
\hline Authority & 25 & 53 & 7 & 58 \\
\hline Regulation of sport hunters & 17 & 36 & 5 & 42 \\
\hline Regulations reduce access to subsistence & 6 & 13 & 0 & 0 \\
\hline Legislation reduces subsistence access & 3 & 6 & 2 & 17 \\
\hline Money to travel to public policy meetings & 1 & 2 & 0 & 0 \\
\hline Bureaucratic barriers to getting hired by National Park Service & 1 & 2 & 0 & 0 \\
\hline Technology & 0 & 1 & 12 & 100 \\
\hline Transportation & 47 & 100 & 12 & 100 \\
\hline Internet for sea ice data & 6 & 13 & 0 & 0 \\
\hline Social media for harvesting information & 14 & 30 & 1 & 83 \\
\hline Knowledge & 47 & 100 & 12 & 100 \\
\hline Skills learned from family/elders & 47 & 100 & 12 & 100 \\
\hline Sea ice safety & 17 & 36 & 4 & 33 \\
\hline Social media for harvesting & 14 & 30 & 1 & 8 \\
\hline Social Relations & 42 & 89 & 8 & 67 \\
\hline Sharing harvest with others & 36 & 77 & 8 & 67 \\
\hline Sharing harvest costs with others & 10 & 21 & 1 & 8 \\
\hline Sharing in work of harvesting & 3 & 6 & 0 & 0 \\
\hline Cultivating relationships with park service & 1 & 2 & 0 & 0 \\
\hline Time & 27 & 57 & 10 & 83 \\
\hline Flexibility to wait until weather or ice is safe & 11 & 23 & 4 & 33 \\
\hline Time off work & 9 & 19 & 1 & 8 \\
\hline Longer travel to get to animals (migration or conditions) & 8 & 17 & 9 & 75 \\
\hline Shorter travel with modern transportation & 1 & 2 & 0 & 0 \\
\hline
\end{tabular}

We're not represented right. So those of us who pay attention to the changing climate or trends ... we don't really get a chance to speak because our representatives are the ones that are going out to Anchorage, to Kotzebue. They're not the ones that are out there noticing the changes (female Kivalina harvester, 55-59 years of age).

The same harvester also voiced that lack of capital as well as social relations further excluded her from attending meetings where she could influence decision making: "We're not invited and I can't pay my own fare."

Harvesters also expressed fear of criminalization if they harvest species in traditional ways. As one harvester put it: "If Fish and Game see you, they'll put you in jail" (female Kivalina harvester, $55-59$ years of age).

Finally, we found that both harvesters in Kotzebue (57\%) and Kivalina $(83 \%)$ described various relationships with time as important for harvest access. We found four sub-mechanisms associated with time; for example, migration patterns of some animals have changed, as have increasing travel distances and time required to harvest (Table 3). Full-time employment also limits time spent subsistence harvesting, especially in the more cashoriented economy in Kotzebue $(19 \%)$ than in Kivalina $(8 \%)$.
Conversely, having fewer time constraints enables flexibility for harvesting during opportune weather and safe sea ice conditions. Finally, one harvester in Kotzebue described how faster, modern transportation technology shortened his travel time to harvest.

\section{Potential adaptation of harvesters to change}

Both harvesters in Kotzebue and Kivalina described a variety of potential adaptations when asked what they would hypothetically do if harvesting animals become more challenging. Primary themes included (1) how they would access animals despite physical alterations in the land and seascape due to climate stressors (30\% of harvesters), (2) how to adapt when harvested species are harder to find $(86 \%)$, and (3) finding alternatives to subsistence harvesting ( $24 \%$ of harvesters).

One response by harvesters to decreased access to animals resulting from climate stressors was using alternative transportation. Specific examples were the use of airplanes to travel to subsistence camps and increased reliance on boat-based hunting instead of snow machines on sea ice. Harvesters in Kivalina and Kotzebue suggested that they would be more cautious before venturing out on the sea ice, and would either wait for information from others who go first or check sea ice conditions on the internet: "We would have to wait. We have no 
choice. Because we're not going to take a chance with our lives" (male Kotzebue harvester, 65-69 years of age).

Harvesters in both groups also indicated they would adapt is by expending more time and effort looking for animals:

\section{If they [animals] would become harder to get to, I'd probably look for other places, other areas. If that means going farther, then so be it (male Kotzebue harvester, 40-44 years of age).}

Harvesters in both communities also suggested that they would shift to new species, which would require time and knowledge about how to harvest new plants and animals, or ask others about where they were successful harvesting to better find animals. Kivalina harvesters also reported that they would rely more on abundant species, and be more frugal with what harvest they had already. Kotzebue harvesters suggested that they would trade fuel for harvest from others, using a combination of access to capital and social relations if they couldn't find animals themselves. They also described harvesting other animals, even if they were less preferable.

Both groups of harvesters also suggested alternatives to harvesting, such as buying more food from the grocery store to supplement their diet, which would require an increased reliance on capital. Growing a vegetable garden was also proposed to supplement wild-harvested foods: "You're not going to be able to afford the fresh produce ... And it's warming up here. You're going to be able to grow stuff" (female Kivalina harvester, 60-64 years of age).

This approach would require both capital for gardening supplies and knowledge of how to garden. One harvester in Kotzebue described how he would turn to political will and lobby legislators:

If I couldn't get to those areas, I'd start petitioning. I'd lobby our legislator. I'd lobby the U.S. Congress and the U.S. Senate. I would rise up and speak (male Kotzebue harvester, 40-44 years of age).

Kivalina harvesters described the need to increasingly rely on cash incomes through jobs that may require access to knowledge and certain skill sets and social relations, as well as potentially decrease time available for subsistence harvesting. Increased reliance on jobs was not suggested by Kotzebue harvesters as an adaptation mechanism.

\section{DISCUSSION}

Current sociological approaches to understanding adaptive capacity to climate change impacts have focused on identifying hypothetical domains, i.e., assets, knowledge, diversity, and governance, that facilitate adaptation (Brooks et al. 2005, Gupta et al. 2010, Whitney et al. 2017). The general reasoning is that investment in these factors will increase adaptive capacity. Yet, much of this work has remained theoretical in nature, especially in relation to how coastal communities actually adapt to climate stressors (Siders 2019, Green et al. 2021). Overlaying these theoretical frameworks from the adaptive capacity literature with the pragmatic mechanisms from access theory has allowed us to provide an empirically grounded understanding of (1) the most salient climate stressors impacting access to coastal harvest in a region of the Alaska Arctic, (2) the mediating mechanisms reported by harvesters to maintain access to coastal subsistence resources during times of rapid environmental change, and (3) potential adaptation responses. Kotzebue harvesters tended to report individual stressors, while Kivalina harvesters were more likely to combine multiple environmental stressors under the umbrella of "climate change." Overall, we found that chronic climate stressors (sea ice retreat, coastal erosion, and changes in weather; in order of importance) were reported rather than acute shocks with respect to harvest access. To mediate these changes, harvesters ubiquitously reported the use of capital, knowledge, technology, and social identity; social relations, authority, and time were also reported at high rates. Finally, we documented potential adaptations, such as increased reliance on new ways to access animals despite landscape changes, switching species or relying on social networks for sharing resources, and exploring alternatives to harvesting.

\section{Climate-driven ecological shifts}

As climate change continues, both access to and abundance of harvested resources will be affected. However, access to some species may stabilize while access to other species will be complicated through continued pressures from loss of habitat and unfavorable environmental conditions with climatic warming (Pecl et al. 2017). The historical seasonal harvest periods that experts described (Fig. 3) matched historical seasonal harvest periods documented by Georgette and Loon (1993). We documented recent temporal shifts of anywhere from one to three weeks earlier start for harvest of three coastal species-bearded seal, beluga, and chum salmon - as well as an earlier end to the bearded seal and beluga harvest depending on ice break up in Kotzebue Sound. We expect the more ice-dependent species, bearded seal and beluga, to experience continued reduction in availability with loss of habitat (Laidre et al. 2015), especially in northwestern Alaska (Moore and Hauser 2019). Although culturally important, beluga harvesting has not occurred on a large scale in Kotzebue Sound since the mid-1960s, with variable and sporadic harvesting since the early 1980s (Georgette and Loon 1993). Thus, beluga harvesting for Kotzebue residents is likely to become even more a hunt of opportunity. However, salmon species may benefit from ice-free waters; for example, recent studies indicate pink salmon (O. gorbuscha) in the Arctic have increased in numbers as warming river temperatures create more hospitable environments (Farley et al. 2020) and new salmon fisheries are beginning to emerge (Carothers et al. 2019). Additionally, we can expect other changes to the ecosystem will have cascading effects, for example, harvesters reported more observations of killer whales that predate on fish and marine mammals, which has also been documented in recent literature (Willoughby et al. 2020). Similarly, harvesters described increases in beaver (Castor canadensis) activity in the region, which can lead to increased hypoxia when beaver dams block lake outlets (Tape et al. 2018).

\section{Asset and non-asset based mediating mechanisms on harvest access}

The capacity of Arctic communities to respond to the climatic impacts that threaten access to these resources is critical. Although every harvester we interviewed described multiple access mechanisms mediating harvest of coastal subsistence resources, the quantity, quality, and accessibility of these access mechanisms varies greatly. For example, while every harvester we 
interviewed had access to some sort of transportation, the type and quality of transportation will become increasingly important in the future. Many individuals described a demand for larger boats as the need to operate boats in an open-water offshore environment becomes more frequent due to the reduction in shore-fast sea ice. The need for larger boats to effectively access offshore, ice-free waters may naturally exclude individuals or families without the financial assets to buy these vessels; wealthier families may gain advantages in access. Access to fuel was also described as critical, and individuals with more capital will have more flexibility to purchase fuel needed to travel farther and more frequently to harvest coastal resources (Godduhn et al. 2014). However, use of capital to purchase fuel may have consequences for other types of household spending. Brinkman et al. (2014) found that $85 \%$ of harvesters in Alaska sacrificed paying for other household needs, i.e., utility bills, so that they could purchase fuel for subsistence costs. Harvesters in the same study also reduced distances traveled for subsistence to minimize fuel use. Although many people we interviewed described adapting by going farther to get to animals or spending more time looking for animals, this may not be a feasible strategy depending on their financial status and other household responsibilities.

Not every access mechanism described in this study required financial resources. Knowledge - the critical skills needed for locating, capturing, and processing subsistence harvest - can often be passed down from generation to generation with little access to capital; however, combining the transfer of knowledge with access to modern technology and hunting equipment could influence knowledge acquisition. Cultural knowledge relating to beliefs, ideological controls, and discursive practices, as well as negotiated systems of meaning, may shape access (Shipton and Goheen 1992), particularly for ritual purposes (Peluso 1996), but with less direct dependence on capital or technology. For example, many harvesters reported the importance of letting the first caribou pass through without harvesting them so that the herd leaders can set the scent of the trail for the rest of the herd. People also described the importance of offering a freshwater, "last drink" in the mouth of a freshly killed seal as sign of respect. These types of knowledge are traditionally passed down across generations through oral tradition; however, the risk of disrupting intergenerational knowledge transfer under various modern societal pressures may influence climate change adaptation (Ford et al. 2020). For example, none of the many beluga hunting practices recorded by anthropologists in the region (Lucier and Vanstone 1995) were mentioned by harvesters, potentially because of the dwindling of beluga populations statewide. Yet, there may be a reverse transfer of knowledge as young people become more adept using access mechanisms related to capital and technology to adapt to new climatic conditions (Galappaththi et al. 2019). One harvester in our study described how his young son may experience these changes:

\footnotetext{
He'll be learning a whole lot of new things when he starts going out there because it's going to be so different than what I know. His generation is going to be experiencing a whole new thing than what we experience. And then he'll be teaching me (male Kivalina harvester, 40-44 years of age).
}

This dynamic nature of knowledge transfer is inherent in Indigenous knowledge systems, which are "rooted in, and informed by, a traditional or customary lifestyle, but adapt to changes and incorporate contemporary information and technology" (Menzies and Butler 2006:7). Thus, mutual knowledge sharing among generations and the growing role of younger community members as important knowledge-holders with respect to changing technologies and landscapes, are inherent to community resilience.

Finally, the sharing of subsistence foods (social relations) is a nonasset-based mechanism to distribute coastal resources in a community (Pearce et al. 2010, Green et al. 2020). Numerous studies have documented the existence of "super-households" where hunters who are efficient at harvesting subsistence foods distribute their extra harvest in the community through complex and robust social networks (Wolfe and Walker 1987, BurnSilver et al. 2016). Although the super-households do require assetbased mechanisms (capital, technology) to procure harvest, the recipients of this sharing may benefit from this cultural value in the absence of assets. As time increasingly becomes a constraint on access, supporting community sharing of resources could be a way to mitigate both the time and cost of subsistence harvesting. For example, the Siglauq (Hunter Support Program), operated by the Maniilaq Association in Kotzebue since 1993, provides supplemental fish and game to elders and funding to tribal governments to support volunteer hunters who harvest traditional foods for those who are unable to do so (https://www. maniilaq.org/siglauq/).

\section{Time to harvest: a new access mechanism?}

Although colonialist influences like wage labor and school have been implicated in reducing time to practice subsistence harvest by others (Condon et al. 1995, Stern 2000), our study documented time constraints and other ways time mediates access to subsistence. Harvesters in Kotzebue, which relies on more wage labor than Kivalina, described how employment conditions restricted their time to practice subsistence and how formal schooling reduces the opportunity for their children to participate in harvest at certain times of the year. Time needed away from work to practice subsistence has increased; harvesters described the need for longer or more frequent trips to find animals because of migration or environmental changes. Although Iñupiat have survived and thrived in a landscape dominated by ice since time immemorial, warming trends in air and sea temperature has led to an increasingly ephemeral frozen landscape. Time to wait for improved weather conditions or for safer ice conditions is increasingly critical. Historically, freeze up in Kotzebue Sound occurred in late October or early November (Farquashon et al. 2018), at which time snow machine travel became possible (Georgette and Loon 1993); however, now, even when there is ice it is not always safe. Thus, harvesters need to have a constant vigilance about their winter traveling conditions and some described conditions changing too fast for traditional knowledge to "catch up." Many people described waiting longer to travel over the ice than in past years or waiting for others with higher risk tolerance to go first, similar to accounts in other Arctic communities (Pearce et al. 2010, Galappaththi et al. 2019). Thus, time as a novel access mechanism will likely become more marked with increasing economic development and climate stressors in rural Alaska. 


\begin{abstract}
Adaptive capacity and future resilience
The communities of Kotzebue and Kivalina rely on coastal subsistence resources that are increasingly affected by climate change. Kivalina, in particular, is one of the most resourcedependent communities in Alaska and most exposed to climate change impacts (IAWG 2009, Himes-Cornell and Kasperski 2015). Increasing adaptive capacity in these and other Arctic communities may require investing in a combination of mechanisms, both asset and non-asset based. The intertwined nature of factors that influence adaptive capacity is not a new concept (Smit and Wandel 2006, many others). Ford et al. (2019) found that Arctic harvesters with both sophisticated transportation equipment (capital and technology) as well as skill in navigating trail conditions (knowledge), were less affected by climatic changes relative to users with more limited equipment and trail expertise. Similarly, asset-poor, small-scale fisher households may be better able to adapt to climate stressors when they combine existing knowledge with other factors, like the agency to diversify livelihoods (Green et al. 2021). We identified both individual access mechanisms and recurring combinations, notably capital and technology, time and social relations, and authority and knowledge. These combinations were important for facilitating access to harvest and should be examined in the context of policies and programs that seek to improve resilience to climate change for coastal communities.
\end{abstract}

Increasing equity of access to these mechanisms among harvesters through a combination of internal community initiatives and government support (e.g., Huntington et al. 2017) can strengthen adaptive responses and community resilience to environmental change. For example, capital and technology were most often described as having assets to invest in larger boats to access offshore, open waters. Sharing of boats among family or other community members may increase access. Further, increasing accessibility of open-water safety education can help make offshore boating safer. Further, the creating of hardened trails for ATV use has been proposed, as ATV travel becomes more common with decreased snow cover. Access to authority and knowledge can be increased simultaneously by assisting harvesters' understanding of public procedures for revising regulations as well as ensuring equitable access to the public process. Specifically, holding meetings in rural as well as urban centers can increase access to the public participation process for harvesters who live in remote villages (Krupa et al. 2020). These meetings can provide a public outreach venue for sharing knowledge about harvesting regulations, communicating about challenges to harvest access, and generating proposals for revising regulations through the appropriate state and federal processes. Although school can reduce time available for children to participate in subsistence harvesting, school-based education and culture camps can also be a source of supporting intergenerational knowledge that is passed down from elders to youth about cultural harvesting rituals (e.g., Camp Sivunniigvik).

\section{Indigenous land stewardship and food sovereignty}

Subsistence harvesters have a unique connection to the land, fostered by tradition and lifelong experience. Traditional ecological knowledge, or Indigenous knowledge, is the system of knowledge gained by experience, observation, and analysis of natural events that is shared among family members, and members of a community. In subsistence practice, that knowledge is used to find, harvest, process, store, and sustain natural resources necessary for food, clothing, shelter, and other needs. Subsistence harvesters are taught at a very young age that they are not to waste subsistence resources, especially fish and wildlife, to take only what is needed when it is needed, to treat all living things with respect, and to not damage the land. Subsistence is a living tradition based on a deep respect for wildlife and for sharing resources with others in their community. Thus, Indigenous knowledge is cumulative, dynamic, place-based, holistic, culturally embedded, and reciprocal with the natural world (Menzies and Butler 2006).

Despite this long tradition of stewardship, Indigenous knowledge has often been disregarded in state and federal resource management policy and process or translated into a form that fits easily within the structure of resource management models (Nadasdy 2003). Resource management institutions privilege Western scientific forms of knowledge in decision making, so that "differing claims to authoritative knowledge ... gain unequal traction in the world according to the power relations of the actors involved" (Griffin 2019:146). Further, "command and control" management policies tend toward compartmentalization of resources and lands (Holling and Meffe 1996), so that holistic approaches more in line with Indigenous systems of stewardship are challenged by bureaucratic rigidity. Complementation of Indigenous knowledge and Western scientific knowledge systems can be a powerful way to understand environmental change and better support community adaptation (Menzies and Butler 2006, Cochran et al. 2013). Here, we found that Indigenous knowledge of climate stressors and environmental data told similar stories of change, but that expert subsistence harvesters provided a broader landscape context and, importantly, mechanisms from an Indigenous perspective that can positively mediate access to harvest under these climate stressors.

Access theory emphasizes the importance of addressing power relations in mediating access, so policy solutions to improving subsistence resource access require recognition of both Indigenous knowledge and the political sovereignty of Indigenous people. Like many other studies using access theory, especially as applied to Indigenous communities, our findings show that access and authority, particularly when stemming from long-standing colonial influences, cannot be disentangled (Sikor and Lund 2009). Peluso and Ribot (2020:301) state that "to control access is to mediate the access of others and includes the power to exclude." Decolonizing access to wild foods through the mechanisms of authority and knowledge is essential to supporting Indigenous food sovereignty. A complex patchwork of state, federal, and corporate land ownership in northwestern Alaska has created barriers to traditional hunting and harvesting practices in Kivalina (Griffin 2019). Western institutions of governance have defined and constrained "subsistence" in ways that have led to criminalization of traditional practices (Griffin 2019), as reflected by the Kivalina research participant who highlighted the threat posed by state agency enforcement when harvesting. Furthermore, capitalist wage labor and formal schooling constrain Indigenous harvesters' time, and therefore access, as exposed by this study and others (Ferguson, Green, and Swanson, unpublished manuscript).

Supporting young Alaska Native leaders in these communities is important for bolstering local solutions to food security and 
sovereignty. Young people we talked to were acutely aware that access to traditional foods provided not only caloric nutrition, but also spiritual and cultural sustenance, essential components of food sovereignty. We found that in addition to thinking about short-term mechanisms like technology that mediate accessing harvest, the younger generations we interviewed were invested in longer term proactive strategies for adaptation, like incorporating cultural knowledge into the school system, reducing plastic waste, and planting trees. Existing initiatives like the Inuit Circumpolar Youth Council-Alaska (https://iccalaska.org/icc-alaska/) and the Kivalina Food Sovereignty Project (https://www.facebook.com/ kvl.food.sovereignty/), which support youth leadership and foster youth-elder relationships, are excellent examples of youth engagement in support of self-determination. How this younger generation invests in long and short-term community-led adaptation related to harvest access will have significant impacts on the resilience of food sovereignty for the region.

\section{CONCLUSION}

We provided a comprehensive overview of access mechanisms in the context of a robust theoretical framework and suggested ways to support them through a combination of local community measures and external agency support. Access theory, which has rarely been applied in marine, and never in Arctic settings (Myers and Hansen 2020), is a valuable tool for systematically approaching mechanisms that constrain or enable access. Other literatures mention some, but not all of the access mechanisms we documented, which we hypothesize is because of the absence of utilizing a framework rather than the absence of the mechanisms themselves. Although this systematic approach is likely to be especially appealing for state or federal agencies to identify broad categories of access mechanisms across diverse geographies and social, cultural, and political settings, the submechanisms we described should not be overlooked. The ways that these broad access mechanisms manifest regionally will be different, and the details of these differences will be important for how to inspire solutions. The utility of our approach is that it can be applied widely to any social-ecological system and used not only to identify environmental stressors and practical climate adaptation strategies, but also ask deeper questions about the power relations and social dynamics within a community that promote or inhibit access to resources. However, although access theory has been applied to Indigenous communities worldwide, we recognize that one of the limitations of the framework is that it necessarily compartmentalizes information, rather than considering mechanisms of access within a holistic system of traditional knowledge and practice. This makes Indigenous leadership and sovereignty even more critical for ensuring access to traditional food systems and resilient communities undergoing climate change.

Responses to this article can be read online at: https://www.ecologyandsociety.org/issues/responses. php/12783

\section{Author Contributions:}

Conceived of the idea for the manuscript ( $K G$ and $A B$ ); procured funding for the research ( $K G$ and $A B)$; supervised organization of the project and manuscript ( $K G$ and $A B$ ); performed research, such as data collection, analysis, or modeling ( $K G$ and $A B$ ); acquired data for the manuscript ( $K G$ and $A B$ ); contributed to methods or models (KG, $A B, M L)$; drafted figures and tables ( $K G$ and $A B)$; drafted the manuscript ( $K G)$; performed critical content reviews and contributed to writing ( $K G, A B, M L$, and $L C)$; acted as cultural liaison; obtained permissions; reviewed for appropriateness to all cultures involved in study (ML); directly shared knowledge or expertise; aided in, or provided documentation or translation $(M L$ and $L C$ ).

\section{Acknowledgments:}

We are grateful to the Native Village of Kotzebue and the Native Village of Kivalina and all the community members that shared their stories with us. This work was supported by the U.S. Department of the Interior, National Park Service, Ocean Alaska Science and Learning Center under a Cooperative Agreement with the University of Alaska Fairbanks (\#P17AC00303) and Stanford University (Emmett, Price, Buckley Families) and Stanford McGee/Levorson funding. We also thank the anonymous reviewers who improved this manuscript through their edits and comments.

\section{Data Availability:}

The datalcode that support the findings of this study are available on request from the corresponding author, [KMG]. None of the datalcode are publicly available because they contain interview data that could compromise the privacy of research participants. Ethical approval for this research study was granted by the Institutional Review Boards at Stanford University (\#40222) and University of Alaska Fairbanks (\#1072840).

\section{LITERATURE CITED}

Bennett, N. J., P. Dearden, G. Murray, and A. Kadfak. 2014. The capacity to adapt?: communities in a changing climate, environment, and economy on the northern Andaman coast of Thailand. Ecology and Society 19(2):5. https://doi.org/10.5751/ ES-06315-190205

Berkes, F., R. Mahon, P. McConney, R. C. Pollnac, and R. S. Pomeroy. 2001. Managing small-scale fisheries: alternative directions and methods. International Development Research Centre, Ottawa, Ontario, Canada.

Bernard, H. R. 1988. Research methods in cultural anthropology. SAGE, Newbury Park, California, USA.

Bernard, H. R. 2006. Research methods in anthropology: qualitative and quantitative approaches. Fourth edition. Altamira, Lanham, Maryland, USA.

Berry, S. 1993. Concentration without privatization? Some consequences of changing patterns of rural land control in Africa. Land and Society in Contemporary Africa 53-75.

Braem, N. M., E. H. Mikow, and M. L. Kostick, editors. 2017. Chukchi Sea and Norton Sound Observation Network: harvest and use of wild resources in 9 communities in Arctic Alaska, 2012-2014. Technical Paper No. 403. Alaska Department of Fish and Game, Division of Subsistence, Juneau, Alaska, USA. 
Brander, K. 2010. Impacts of climate change on fisheries. Journal of Marine Systems 79(3-4):389-402. https://doi.org/10.1016/j. jmarsys.2008.12.015

Braun, V., and V. Clarke. 2006. Using thematic analysis in psychology. Qualitative Research in Psychology 3(2):77-101. https://doi.org/10.1191/1478088706qp063oa

Brierley, A. S., and M. J. Kingsford. 2009. Impacts of climate change on marine organisms and ecosystems. Current Biology 19 (14):R602-R614. https://doi.org/10.1016/j.cub.2009.05.046

Brinkman, T., K. T. B. Maracle, J. Kelly, M. Vandyke, A. Firmin, and A. Springsteen. 2014. Impact of fuel costs on high-latitude subsistence activities. Ecology and Society 19(4):18. https://doi. org/10.5751/ES-06861-190418

Brinkman, T. J., W. D. Hansen, F. S. Chapin III, G. Kofinas, S. BurnSilver, and T. S. Rupp. 2016. Arctic communities perceive climate impacts on access as a critical challenge to availability of subsistence resources. Climatic Change 139:413-427. https://doi. org/10.1007/s10584-016-1819-6

Brooks, N., W. N. Adger, and P. M. Kelly. 2005. The determinants of vulnerability and adaptive capacity at the national level and the implications for adaptation. Global Environmental Change 15(2):151-163. https://doi.org/10.1016/j.gloenvcha.2004.12.006

Burch, E. S. 1975. Eskimo kinsmen: changing family relationships in northwest Alaska. West, St. Paul, Minnesota, USA.

Burch, E. S. 1998. The Inupiaq Eskimo Nations of northwest Alaska. University of Alaska Press, Fairbanks, Alaska, USA.

BurnSilver, S., J. Magdanz, R. Stotts, M. Berman, and G. Kofinas. 2016. Are mixed economies persistent or transitional? Evidence using social networks from Arctic Alaska. American Anthropologist 118(1):121-129. https://doi.org/10.1111/aman.12447

Calderón-Contreras, R., and C. S. White. 2020. Access as the means for understanding social-ecological resilience: bridging analytical frameworks. Society \& Natural Resources 33 (2):205-223. https://doi.org/10.1080/08941920.2019.1597233

Carothers, C., T. L. Sformo, S. Cotton, J. C. George, and P. A. Westley. 2019. Pacific Salmon in the rapidly changing Arctic. Arctic 72(3):273-288. https://doi.org/10.14430/arctic68876

Cinner, J. E., C. Huchery, C. C. Hicks, T. M. Daw, N. Marshall, A. Wamukota, and E. H. Allison. 2015. Changes in adaptive capacity of Kenyan fishing communities. Nature Climate Change 5(9):872-876. https://doi.org/10.1038/nclimate2690

Cisneros-Montemayor, A. M., D. Pauly, L. V. Weatherdon, and Y. Ota. 2016. A global estimate of seafood consumption by coastal indigenous peoples. PLoS ONE 11(12):e0166681. https://doi. org/10.1371/journal.pone.0166681

Cochran, P., O. H. Huntington, C. Pungowiyi, S. Tom, F. S. Chapin III, H. P. Huntington, N. G. Maynard, and S. F. Trainor. 2013. Indigenous frameworks for observing and responding to climate change in Alaska. Pages 49-59 in J. Koppel Maldonado, B. Colombi, and R. Pandya, editors. Climate change and Indigenous peoples in the United States. Springer, Cham, Switzerland. https://doi.org/10.1007/978-3-319-05266-3 5
Cold, H. S., T. J. Brinkman, C. L. Brown, T. N. Hollingsworth, D. R. N. Brown, and K. M. Heeringa. 2020. Assessing vulnerability of subsistence travel to effects of environmental change in Interior Alaska. Ecology and Society 25(1):20. https:// doi.org/10.5751/ES-11426-250120

Condon, R. G., P. Collings, and G. Wenzel. 1995. The best part of life: subsistence hunting, ethnicity, and economic adaptation among young adult Inuit males. Arctic 48(1):31-46. https://doi. org/10.14430/arctic1222

Corell, R. W. 2006. Challenges of climate change: an Arctic perspective. Ambio: A Journal of the Human Environment 35 (4):148-152. https://doi.org/10.1579/0044-7447(2006)35[148:COCCAA] 2.0. $\mathrm{CO} ; 2$

Denzin, N. K. 2009. The research act: a theoretical introduction to sociological methods. Aldine Transaction, New York, New York, USA. https://doi.org/10.4324/9781315134543

Department for International Development (DFID). 2011. Defining disaster resilience: A DFID Approach Paper. DFID, London, UK. [online] URL: https://assets.publishing. service.gov. uk/government/uploads/system/uploads/attachment_data/file/186874/ defining-disaster-resilience-approach-paper.pdf

Farley Jr, E. V., J. M. Murphy, K. Cieciel, E. M. Yasumiishi, K. Dunmall, T. Sformo, and P. Rand. 2020. Response of Pink salmon to climate warming in the northern Bering Sea. Deep Sea Research Part II: Topical Studies in Oceanography 177:104830. https://doi. org/10.1016/j.dsr2.2020.104830

Farquharson, L. M., D. H. Mann, D. K. Swanson, B. M. Jones, R. M. Buzard, and J. W. Jordan. 2018. Temporal and spatial variability in coastline response to declining sea-ice in northwest Alaska. Marine Geology 404:71-83. https://doi.org/10.1016/j. margeo.2018.07.007

Flick, U., E. Von Kardorff, and I. Steinke. 2004. What is qualitative research? An introduction to the field. Pages 3-12 in U. Flick, E. Von Kardoff, and I. Steinke, editors. A companion to qualitative research. SAGE, London, UK.

Ford, J. D., D. Clark, T. Pearce, L. Berrang-Ford, L. Copland, J. Dawson, M. New, and S. L. Harper. 2019. Changing access to ice, land and water in Arctic communities. Nature Climate Change 9 (4):335-339. https://doi.org/10.1038/s41558-019-0435-7

Ford, J. D., N. King, E. K. Galappaththi, T. Pearce, G. McDowell, and S. L. Harper. 2020. The resilience of Indigenous peoples to environmental change. One Earth 2(6):532-543. https://doi. org/10.1016/j.oneear.2020.05.014

Galappaththi, E. K., J. D. Ford, and E. M. Bennett. 2019. A framework for assessing community adaptation to climate change in a fisheries context. Environmental Science \& Policy 92:17-26. https://doi.org/10.1016/j.envsci.2018.11.005

Georgette, S., and H. Loon. 1993. Subsistence use of fish and wildlife in Kotzebue, a Northwest Alaska regional center (No. 167). Alaska Department of Fish and Game, Division of Subsistence, Juneau, Alaska, USA.

Gibbs, A. E., A. G. Snyder, and B. M. Richmond. 2019. National assessment of shoreline change-historical shoreline change along the north coast of Alaska, Icy Cape to Cape Prince of Wales. 
Open-File Report 2019-1146. U.S. Geological Survey, Pacific Science Center, Santa Cruz, California, USA. https://doi. org/10.3133/ofr20191146

Godduhn, A. R., N. M. Braem, and M. L. Kostick. 2014. Subsistence wildlife harvests in Kotzebue, Alaska, 2012-2013. Alaska Department of Fish and Game, Division of Subsistence, Juneau, Alaska, USA.

Government Accountability Office (GAO). 2003. Alaska Native villages: most are affected by flooding and erosion, but few qualify for federal assistance. GAO, Washington, D.C., USA. [online] URL: https://www.gao.gov/assets/gao-04-142.pdf

Green, K. M., S. S. Fletcher, A. H. Beaudreau, and S. M. Whiting. 2020. Iñupiaq values in subsistence harvesting: applying the community voice method in northwest Alaska. Society \& Natural Resources 33(1):122-137. https://doi.org/10.1080/08941920.2019.1660935

Green K. M., J. C. Selgrath, T. H. Frawley, W. K. Oestreich, E. J. Mansfield, J. Urteaga, S. S. Swanson, F. N. Santana, S. J. Green, J. Naggea, and L. B. Crowder. 2021. How adaptive capacity shapes the response Adapt, React, Cope to climate impacts: insights from small-scale fisheries. Climatic Change 164(15). https://doi. org/10.1007/s10584-021-02965-W

Griffin, P. J. 2019. Breathing room: climate displacement, biopolitics, and Indigenous sovereignty in Northwest Alaska. Dissertation. University of Washington, Seattle, Washington, USA.

Guest, G., A. Bunce, and L. Johnson. 2006. How many interviews are enough? An experiment with data saturation and variability. Field Methods 18(1):59-82. https://doi.org/10.1177/1525822X05279903

Gupta, J., C. Termeer, J. Klostermann, S. Meijerink, M. van den Brink, P. Jong, S. Nooteboom, and E. Bergsma. 2010. The adaptive capacity wheel: a method to assess the inherent characteristics of institutions to enable the adaptive capacity of society. Environmental Science \& Policy 13(6):459-471. https:// doi.org/10.1016/j.envsci.2010.05.006

Himes-Cornell, A., and S. Kasperski. 2015. Assessing climate change vulnerability in Alaska's fishing communities. Fisheries Research 162:1-11. https://doi.org/10.1016/j.fishres.2014.09.010

Holling, C. S., and G. K. Meffe. 1996. Command and control and the pathology of natural resource management. Conservation Biology 10(2):328-337. https://doi.org/10.1046/j.1523-1739.1996.10020328. $\underline{\mathrm{X}}$

Huntington, H. P., A. Begossi, S. Fox Gearheard, B. Kersey, P. A. Loring, T. Mustonen, P. K. Paudel, R. A. M. Silvano, and R. Vave. 2017. How small communities respond to environmental change: patterns from tropical to polar ecosystems. Ecology and Society 22(3):9. https://doi.org/10.5751/ES-09171-220309

Huntington, H. P., S. L. Danielson, F. K. Wiese, M. Baker, P. Boveng, J. J. Citta, A. De Robertis, D. M. Dickson, E. Farley, J. C. George, et al. 2020. Evidence suggests potential transformation of the Pacific Arctic ecosystem is underway. Nature Climate Change 10:342-348. https://doi.org/10.1038/s41558-020-0695-2

Huntington, H. P., L. T. Quakenbush, and M. Nelson. 2016. Effects of changing sea ice on marine mammals and subsistence hunters in northern Alaska from traditional knowledge interviews. Biology Letters 12(8):20160198. https://doi. org/10.1098/rsbl.2016.0198

Immediate Action Workgroup (IAWG). 2009. Recommendations to the governor's subcabinet on climate change. IAWG, Juneau, Alaska. [online] URL: https://www.denali.gov/wp-content/ uploads/2018/10/Reccomendations-to-the-Governors-Subcabineton-Climate-Change.pdf

Interagency Arctic Research Policy Committee (IARPC). 2018. Principles for conducting research in the Arctic. IARPC, Washington, D.C., USA.

Inuit Circumpolar Council-Alaska (ICC-Alaska). 2015. Alaskan Inuit food security conceptual framework: how to assess the Arctic from an Inuit perspective. ICC-Alaska, Anchorage, Alaska, USA. [online] URL: http://iccalaska.org/wp-icc/wpcontent/uploads/2016/03/Food-Security-Summary-and-RecommendationsReport.pdf

Kerin, E. J., and H. K. Lin. 2010. Fugitive dust and human exposure to heavy metals around the Red Dog Mine. Pages 49-63 in D. M. Whitacre, editor. Reviews of environmental contamination and toxicology. Volume 206. Springer, New York, New York, USA. https://doi.org/10.1007/978-1-4419-6260-7_3

Kovach, M. 2010. Conversational method in Indigenous research. First Peoples Child and Family Review 14(1):123-136.

Krupa, M. B. , M. McCarthy Cunfer, and S. J. Clark. 2020. Who's winning the public process? How to use public documents to assess the equity, efficiency, and effectiveness of stakeholder engagement. Society \& Natural Resources 33(5):612-633. https:// doi.org/10.1080/08941920.2019.1665763

Laidre, K. L., H. Stern, K. M. Kovacs, L. Lowry, S. E. Moore, E. V. Regehr, S. H. Ferguson, Ø. Wiig, P. Boveng, R. P. Angliss, E. W. Born, D. Litovka, L. Quakenbush, C. Lydersen, D. Vongraven, and F. Ugarte. 2015. Arctic marine mammal population status, sea ice habitat loss, and conservation recommendations for the 21st century. Conservation Biology 29(3):724-737. https://doi. org/10.1111/cobi.12474

Laidre, K. L., I. Stirling, L. F. Lowry, Ø. Wiig, M. P. HeideJørgensen, and S. H. Ferguson. 2008. Quantifying the sensitivity of Arctic marine mammals to climate-induced habitat change. Ecological Applications 18(sp2):S97-S125. https://doi. org/10.1890/06-0546.1

Lazarus, R. S. 2006. Stress and emotion: a new synthesis. Springer, New York, New York, USA.

Lewis, J. P., and K. Boyd. 2013. Forward steps and missteps: What we've learned through the process of conducting CBPR research in rural Alaska. Journal of Indigenous Research 2(1):3.

Lepóla, M. 2010. The Aleuts and the Pacific Eskimo in the colonial economy of Russian Alaska in the mid 19th century. The Arctic and Antarctic International Journal of Circumpolar Socio-Cultural Issues 4(4):67.

Lucier, C. V., and J. W. VanStone. 1995. Traditional beluga drives of the Iñupiat of Kotzebue Sound, Alaska. Fieldiana. Anthropology 25:ii-91. https://doi.org/10.5962/bhl.title.5339 
Magdanz, J. S., N. Braem, B. C. Robbins, and D. S. Koster. 2010. Subsistence harvests in northwest Alaska, Kivalina and Noatak, 2007. Technical Paper 354. Alaska Department of Fish and Game, Kotzebue, Alaska, USA.

Magdanz, J. S., H. Smith, N. Braem, P. Fox, and D. S. Koster. 2011. Patterns and trends in subsistence fish harvests, northwest Alaska, 1994-2004. Final Paper Study No. FIS:07-151. Alaska Department of Fish and Game, Kotzebue, Alaska.

Mahoney, A. R., H. Eicken, A. G. Gaylord, and R. Gens. 2014. Landfast sea ice extent in the Chukchi and Beaufort Seas: the annual cycle and decadal variability. Cold Regions Science and Technology 103:41-56. https://doi.org/10.1016/j.coldregions.2014.03.003

Maslanik, J. A., C. Fowler, J. Stroeve, S. Drobot, J. Zwally, D. Yi, and W. Emery. 2007. A younger, thinner Arctic ice cover: increased potential for rapid, extensive sea-ice loss. Geophysical Research Letters 34(24). https://doi.org/10.1029/2007GL032043

Menzies C. R., and C. Butler. 2006. Introduction: understanding ecological knowledge. Pages 1-17 in C. R. Menzies, editor. Traditional ecological knowledge and natural resource management. University of Nebraska Press, Lincoln, Nebraska, USA.

Moerlein, K. J., and C. Carothers. 2012. Total environment of change: impacts of climate change and social transitions on subsistence fisheries in northwest Alaska. Ecology and Society 17(1):10. https://doi.org/10.5751/ES-04543-170110

Moore, S. E., and D. D. Hauser. 2019. Marine mammal ecology and health: finding common ground between conventional science and indigenous knowledge to track arctic ecosystem variability. Environmental Research Letters 14(7):075001. https:// doi.org/10.1088/1748-9326/ab20d8

Morley, J. W., R. L. Selden, R. J. Latour, T. L. Frölicher, R. J. Seagraves, and M. L. Pinsky. 2018. Projecting shifts in thermal habitat for 686 species on the North American continental shelf. PLoS ONE 13(5):e0196127. https://doi.org/10.1371/journal. pone. 0196127

Myers, R., and C. P. Hansen. 2020. Revisiting a theory of access: a review. Society \& Natural Resources 33:(2):146-166. https://doi. org/10.1080/08941920.2018.1560522

Nadasdy, P. 2003. Hunters and bureaucrats: power, knowledge, and aboriginal-state relations in the southwest Yukon. University of British Columbia Press, Vancouver, British Columbia, Canada.

NVivo qualitative data analysis software. 2011. Version 11. QSR International Pty Ltd, Melbourne, Australia.

Pearce, T., B. Smit, F. Duerden, J. D. Ford, A. Goose, and F. Kataoyak. 2010. Inuit vulnerability and adaptive capacity to climate change in Ulukhaktok, Northwest Territories, Canada. Polar Record 46(2):157-177. https://doi.org/10.1017/S0032247409008602

Pecl, G. T., M. B. Araújo, J. D. Bell, J. Blanchard, T. C. Bonebrake, I.-C. Chen, T. D. Clark, R. K. Colwell, F. Danielsen, B. Evengård, L. Falconi, S. Ferrier, S. Frusher, R. A. Garcia, R. B. Griffis, A. J. Hobday, C. Janion-Scheepers, M. A. Jarzyna, S. Jennings, J. Lenoir, H. I. Linnetved, V. Y. Martin, P. C. McCormack, J.
McDonald, N. J. Mitchell, T. Mustonen, J. M. Pandolfi, N. Pettorelli, E. Popova, S. A. Robinson, B. R. Scheffers, J. D. Shaw, C. J. B. Sorte, J. M. Strugnell, J. M. Sunday, M.-N. Tuanmu, A. Vergés, C. Villanueva, T. Wernberg, E. Wapstra, and S. E. Williams. 2017. Biodiversity redistribution under climate change: impacts on ecosystems and human well-being. Science 355(6332). https://doi.org/10.1126/science.aai9214

Peluso, N. L. 1996. Fruit trees and family trees in an anthropogenic forest: ethics of access, property zones, and environmental change in Indonesia. Comparative Studies in Society and History 38(3):510-548. https://doi.org/10.1017/ $\underline{\text { S0010417500020041 }}$

Peluso, N. L., and J. Ribot. 2020. Postscript: a theory of access revisited. Society \& Natural Resources 33(2):300-306. https://doi. org/10.1080/08941920.2019.1709929

Pinstrup-Andersen, P. 2009. Food security: definition and measurement. Food Security 1(1):5-7. https://doi.org/10.1007/ s12571-008-0002-y

Post, E., R. B. Alley, T. R. Christensen, M. Macias-Fauria, B. C. Forbes, M. N. Gooseff, A. Iler, J. T. Kerby, K. L. Laidre, M. E. Mann, J. Olofsson, J. C. Stroeve, F. Ulmer, R. A. Virginia, and M. Wang. 2019. The polar regions in a $2^{\circ} \mathrm{C}$ warmer world. Science Advances 5(12):eaaw9883. https://doi.org/10.1126/sciadv.aaw9883

Ribot, J. C., and N. L. Peluso. 2003. A theory of access. Rural Sociology 68(2):153-181. https://doi.org/10.1111/j.1549-0831.2003. tb00133.x

Satterthwaite-Phillips, D. A., C. Krenz, G. Gray, and L. Dodd. 2016. Iñuniałiqput ililugu nunayyuanun (Documenting our way of life with maps): Northwest Arctic Borough subsistence mapping project. Vol. 1. Northwest Arctic Borough, Kotzebue, Alaska, USA.

Saunders, B., J. Sim, T. Kingstone, S. Baker, J. Waterfield, B. Bartlam, H. Burroughs, and C. Jinks. 2018. Saturation in qualitative research: exploring its conceptualization and operationalization. Quality \& Quantity 52(4):1893-1907. https:// doi.org/10.1007/s11135-017-0574-8

Schmidhuber, J., and F. N. Tubiello. 2007. Global food security under climate change. Proceedings of the National Academy of Sciences of the United States of America 104(50):19703-19708. https://doi.org/10.1073/pnas.0701976104

Seggel, A., and C. De Young. 2016. Climate change implications for fisheries and aquaculture: summary of the findings of the Intergovernmental Panel on Climate Change Fifth Assessment Report. FAO fisheries and aquaculture circular(C1122):I. Food and Agriculture Organization, Rome, Italy.

Shipton, P., and M. Goheen. 1992. Introduction. Understanding African land-holding: power, wealth, and meaning. Africa 62 (3):307-325. https://doi.org/10.2307/1159746

Siders, A. R. 2019. Adaptive capacity to climate change: a synthesis of concepts, methods, and findings in a fragmented field. Wiley Interdisciplinary Reviews: Climate Change 10(3):e573. https://doi.org/10.1002/wcc.573 
Sikor, T., and C. Lund. 2009. Access and property: a question of power and authority. Development and Change 40(1):1-22. https://doi.org/10.1111/j.1467-7660.2009.01503.x

Smit, B., and J. Wandel. 2006. Adaptation, adaptive capacity and vulnerability. Global Environmental Change 16(3):282-292. https://doi.org/10.1016/j.gloenvcha.2006.03.008

Stern, P. 2000. Subsistence: work and leisure. Études/Inuit/Studies 24(1):9-24.

Sumaila, U. R., W. W. L. Cheung, V. W. Y. Lam, D. Pauly, and S. Herrick. 2011. Climate change impacts on the biophysics and economics of world fisheries. Nature Climate Change 1 (9):449-456. https://doi.org/10.1038/nclimate1301

Tape, K. D., B. M. Jones, C. D. Arp, I. Nitze, and G. Grosse. 2018. Tundra be dammed: beaver colonization of the Arctic. Global Change Biology 24(10):4478-4488. https://doi.org/10.1111/ gcb. 14332

Teh, L., and U. Sumaila. 2013. Contribution of marine fisheries to worldwide employment. Fish and Fisheries 14(1):77-88. https:// doi.org/10.1111/j.1467-2979.2011.00450.x

Topkok, C. S. A. 2015. Iñupiat Ilitqusiat: inner views of our Inupiaq values. Dissertation. University of Alaska Fairbanks, Fairbanks, Alaska, USA.

U.S. Census Bureau. 2010. Population and housing unit counts, CPH-2-3. U.S. Government Printing Office, Washington, D.C., USA. [online] URL: https://www.census.gov/library/publications/2012/ dec/cph-2.html

U.S. Congress. 1980. Alaska National Interest Lands Conservation Act (ANILCA). Public Law 96-487, 94 Stat. 2371-2551. U.S. Congress, Washington, D.C., USA.

Via Campesina. 2008. La Via Campesina policy documents. 5th Conference Mozambique, 16th to 23rd October. [online] URL: https://viacampesina.org/en/wp-content/uploads/sites/2/2010/03/ BOOKLET-EN-FINAL-min.pdf

Whiting, A., D. Griffith, S. Jewett, L. Clough, W. Ambrose, and J. Johnson. 2011. Combining Inupiaq and scientific knowledge: ecology in northern Kotzebue Sound, Alaska. Alaska Sea Grant Program, University of Alaska Fairbanks, Fairbanks, Alaska, USA. https://doi.org/10.4027/ciskenksa.2011

Whitney, C. K., N. J. Bennett, N. C. Ban, E. H. Allison, D. Armitage, J. L. Blythe, J. M. Burt, W. Cheung, E. M. Finkbeiner, M. Kaplan-Hallam, I. Perry, N. J. Turner, and L. Yumagulova. 2017. Adaptive capacity: from assessment to action in coastal social-ecological systems. Ecology and Society 22(2):22. https:// doi.org/10.5751/ES-09325-220222

Whyte, K. P. 2018. Food sovereignty, justice, and Indigenous peoples: an essay on settler colonialism and collective continuance. Pages 345-366 in A. Barnhill, M. Budolfson, and T. Doggett, editors. The Oxford handbook of food ethics. Oxford University Press, Oxford, UK. https://doi.org/10.1093/ oxfordhb/9780199372263.013.34

Willoughby, A. L., M. C. Ferguson, R. Stimmelmayr, J. T. Clarke, and A. A. Brower. 2020. Bowhead whale (Balaena mysticetus) and killer whale (Orcinus orca) co-occurrence in the U.S. Pacific
Arctic, 2009-2018: evidence from bowhead whale carcasses. Polar Biology 43:1669-1679. https://doi.org/10.1007/s00300-020-02734y

Wolfe, R. J., and R. J. Walker. 1987. Subsistence economies in Alaska: productivity, geography, and development impacts. Arctic Anthropology 24(2):56-81. [online] URL: http://www. jstor.org/stable/40316144.

Young, T., E. C. Fuller, M. M. Provost, K. E. Coleman, K. St. Martin, B. J. McCay, and M. L. Pinsky. 2019. Adaptation strategies of coastal fishing communities as species shift poleward. ICES Journal of Marine Science 76(1):93-103. https:// doi.org/10.1093/icesjms/fsy140 
Appendix 1. Interview Protocol for Subsistence Harvesters

Part 1: Access to Subsistence Resources

1. How long have you lived in Alaska? In your current town?

2. How long have you been harvesting here? Who did you learn from? How many days do you harvest?

For the next questions, we will have a map to look at as a tool.

3. How do you get to the coast around Cape Krusenstern or Kotzebue Sound to harvest or hunt? Check all that apply. Has this changed?
$\square$ ATVs
$\square$ boat
$\square$ snow machine

4. Do you use ATVs in CAKR? If so, do you use beaches or another trail? Do you stay on the trail? Who did you learn about the trails from? Do you remember trails changing? Why are you using the trail?

5. Based on the table below, what months of the year do you currently harvest these animals? Has this changed over time? Is there anything else that you harvest that is not on this list?

\begin{tabular}{|l|l|l|l|l|l|l|l|l|l|l|l|l|}
\hline Species & J & F & M & A & M & J & J & A & S & O & N & D \\
\hline Ugruk & & & & & & & & & & & & \\
\hline Other seals & & & & & & & & & & & & \\
\hline Beluga & & & & & & & & & & & & \\
\hline Whitefish & & & & & & & & & & & & \\
\hline Sheefish & & & & & & & & & & & & \\
\hline Salmon & & & & & & & & & & & & \\
\hline Walrus & & & & & & & & & & & & \\
\hline Seabird/eggs & & & & & & & & & & & & \\
\hline Crab & & & & & & & & & & & & \\
\hline Grayling & & & & & & & & & & & & \\
\hline
\end{tabular}

6. Are you traveling shorter, longer, or about the same compared to the past? [Have map as a tool if needed. Clarify when "past" was. If time or distance to harvest has changed, ask them why. When did this change? Draw on the map where they talk about. Are there places you don't go to anymore and why? Are there new places that you go to now?] 
7. What do you think you will do if these areas [in the land or ocean] become harder to get to?

8. Have you noticed any changes in when animals are available to harvest?

9. What is the most important thing you harvest? [Do you use social media (i.e. Facebook for harvest information?

10. Are there traditional rules for the places where you harvest? If so, what are they? What is the best way to enforce these rules?

11. What is the biggest impact on your ability to access subsistence resources on the coast?

Part 2: Subsistence Management/Policy

12. How do you communicate with state or federal managers about these harvest access challenges? [e.g.Do you go to SRC or other policy meetings? Why or why not?]

13. Are there specific things you think could be done to (better) manage subsistence resources?

14. How would you describe your and other harvesters' relationships with NPS and other managers?

15. What do you think [based on what they said earlier] could be done to resolve these issues? 
Appendix 2. Summary of climate stressors and potential impacts to subsistence harvest

Table A2.1 Description of climate stressors, and potential impacts to harvesting subsistence resources as reported by harvesters.

\begin{tabular}{|c|c|c|c|c|}
\hline Physical Stressor & $\begin{array}{l}\text { Kotzebue and Kivalina } \\
\text { Harvesters } \\
\text { Description }\end{array}$ & Quantitative trend & $\begin{array}{l}\text { Harvester } \\
\text { perception }\end{array}$ & Impact on access \\
\hline Sea ice & $\begin{array}{l}\text { Extent, thickness, duration of } \\
\text { sea ice reduced }\end{array}$ & $\begin{array}{l}\text { Declining sea ice extent and } \\
\text { thickness in Kotzebue } \\
\text { Sound; Chukchi Sea } \\
\text { (Mahoney et al. 2014; } \\
\text { Farquharson et al. } 2018\end{array}$ & Agree & $\begin{array}{l}\text { Harder and more dangerous to access } \\
\text { animals that use the sea edge, short } \\
\text { window of time to hunt ice-dependent } \\
\text { species, people dying in unsafe ice } \\
\text { conditions. }\end{array}$ \\
\hline Weather & $\begin{array}{l}\text { Changes in rain, snow, wind } \\
\text { outside of 'normal' weather } \\
\text { patterns for the region }\end{array}$ & $\begin{array}{l}\text { Increased air and sea } \\
\text { temperature in Kivalina and } \\
\text { Kotzebue (NOAA Climate } \\
\text { Data Online Database) }\end{array}$ & Agree & $\begin{array}{l}\text { Harder to travel on snow machine in } \\
\text { low snow cover, unpleasant to } \\
\text { travel/hunt in wet/windy conditions, } \\
\text { harder to process (dry fish and meat) in } \\
\text { rainy conditions, wind can move } \\
\text { broken ice and make for difficult } \\
\text { boating conditions, animals harder to } \\
\text { hunt in wind. }\end{array}$ \\
\hline Coastal erosion & $\begin{array}{l}\text { Erosion (loss of habitat) of } \\
\text { coastal shorelines }\end{array}$ & $\begin{array}{l}\text { Accreting and erosion spots } \\
\text { in Kivalina and Kotzebue } \\
\text { (Gibbs et al. 2019; Fang et } \\
\text { al. 2019) }\end{array}$ & $\begin{array}{l}\text { Agree with } \\
\text { erosion areas, } \\
\text { accretion areas not } \\
\text { discussed }\end{array}$ & $\begin{array}{l}\text { Harder to travel around places where } \\
\text { beach has eroded, people losing } \\
\text { allotment land or physical structures. }\end{array}$ \\
\hline Snow cover & Decreased snow cover & $\begin{array}{l}\text { Earlier end to the continuous } \\
\text { snow pack in Cape } \\
\text { Krusenstern National } \\
\text { Monument (Euskirchen et al. } \\
\text { 2016; Swanson 2017) }\end{array}$ & $\begin{array}{l}\text { Agree, although } \\
\text { specific details of } \\
\text { snow thickness or } \\
\text { snow cover end } \\
\text { dates not detailed }\end{array}$ & $\begin{array}{l}\text { Harder to travel by snow machine, } \\
\text { snow machine trails not in good } \\
\text { condition, rain on snow events } \\
\text { dangerous for caribou. }\end{array}$ \\
\hline High water & $\begin{array}{l}\text { Flooding of coastal areas, } \\
\text { happens in certain storm and } \\
\text { wind conditions. }\end{array}$ & $\begin{array}{l}\text { Increased flooding and } \\
\text { erosion in Kivalina (Fang et } \\
\text { al. 2019); data unavailable } \\
\text { for Kotzebue }\end{array}$ & $\begin{array}{l}\text { Agree (Kivalina; } \\
\text { data not available } \\
\text { for Kotzebue) }\end{array}$ & $\begin{array}{l}\text { Increased coastal erosion makes areas } \\
\text { more difficult to access. }\end{array}$ \\
\hline $\begin{array}{l}\text { Permafrost } \\
\text { degradation }\end{array}$ & $\begin{array}{l}\text { Melting of frozen permafrost } \\
\text { that causes uneven ground, } \\
\text { erosion, etc. }\end{array}$ & $\begin{array}{l}\text { Increased ground } \\
\text { temperatures in Northwest } \\
\text { Alaska (Batir et al. 2017) }\end{array}$ & Agree & $\begin{array}{l}\text { Harder to use ATVs or snow machine } \\
\text { on melted permafrost, increases } \\
\text { sinkholes and erosion of access trails. }\end{array}$ \\
\hline
\end{tabular}


Kotzebue Mean Monthly Temperature, 1998-2020
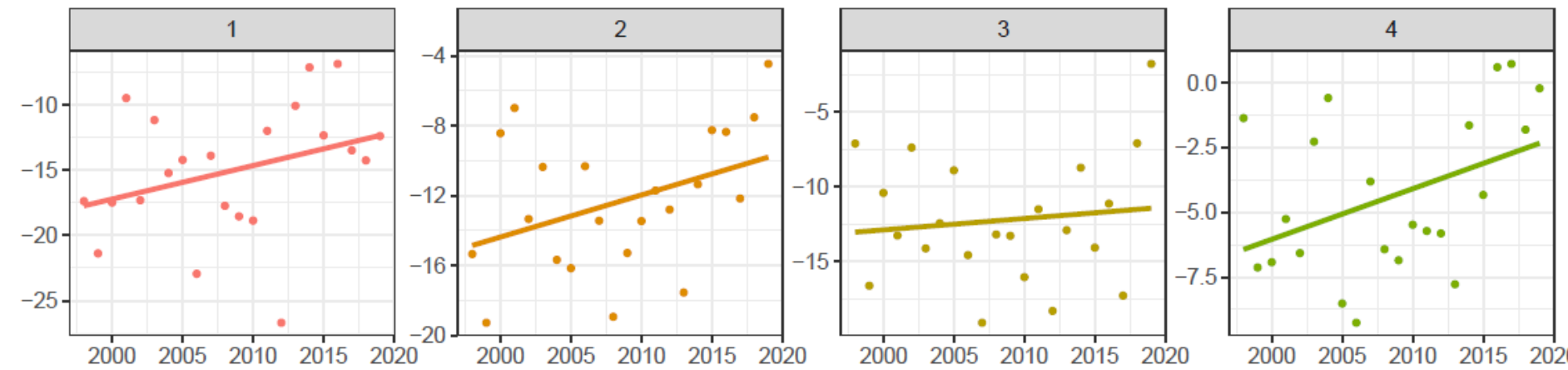

Month
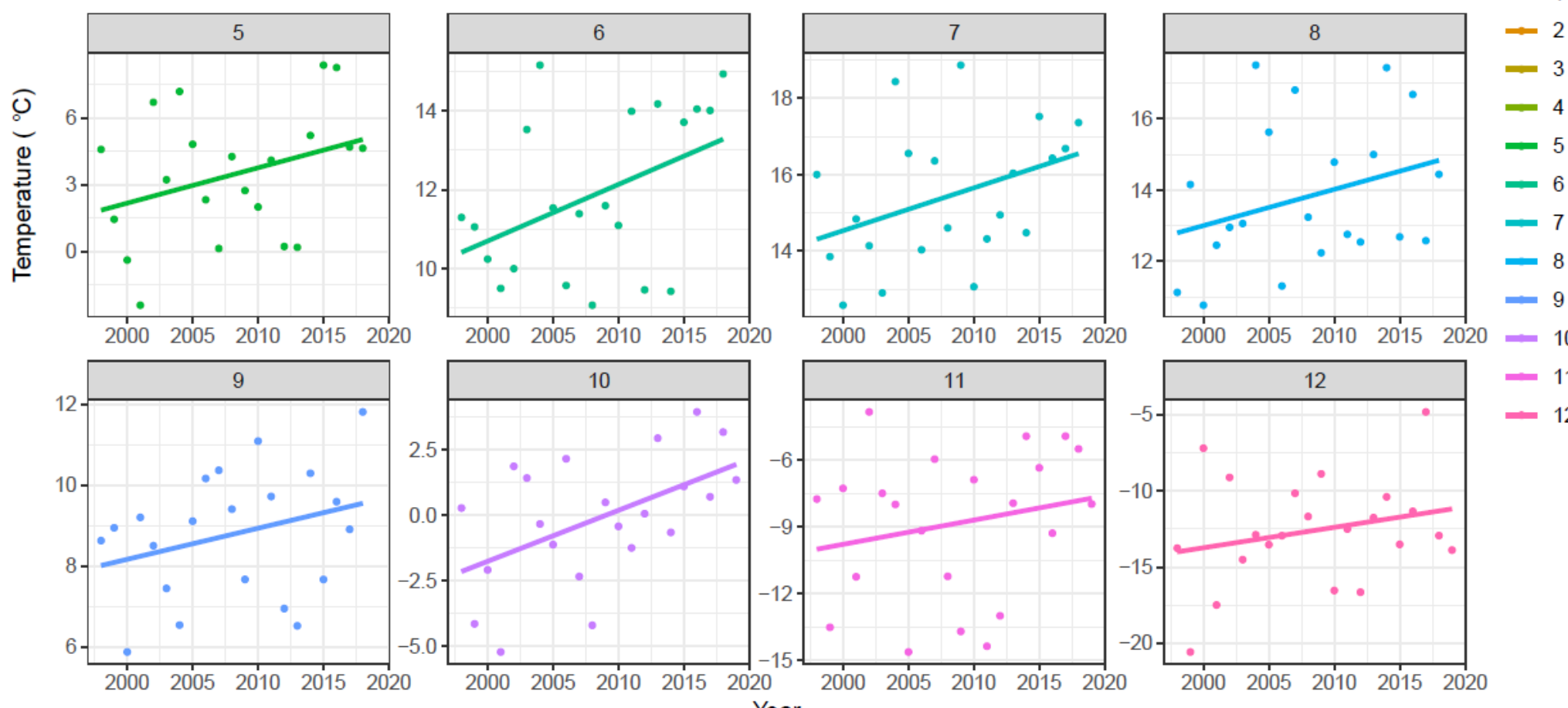

$-11$

$-12$

Figure A2.1 Trends in air temperature in Kotzebue, Alaska, from 1998 to 2020. Points are the average of daily temperature values for each month. Lines are predicted values from linear regression models fitted to the data (see Table A2.2). Data source: NOAA National Center for Environmental Information. 
Kivalina Mean Monthly Temperature, 1998-2020
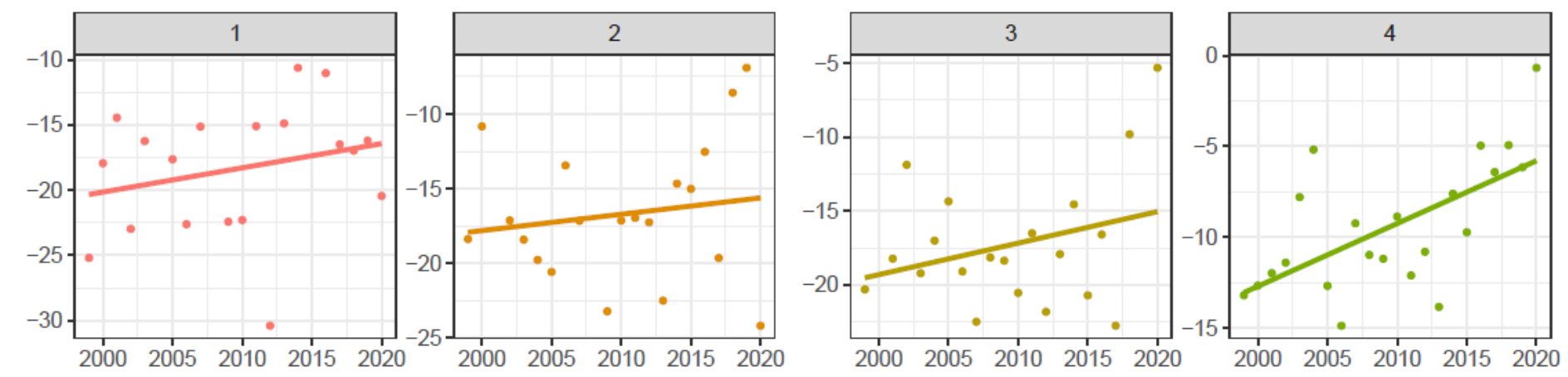

Month
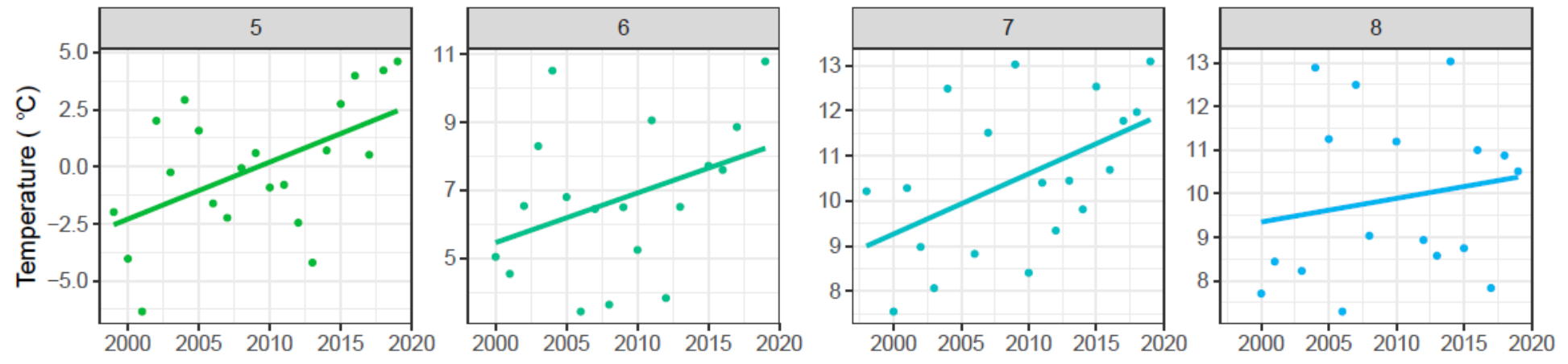

$-1$

$-2$

$-3$

$-4$

$-5$

$-6$

$-7$

$-8$
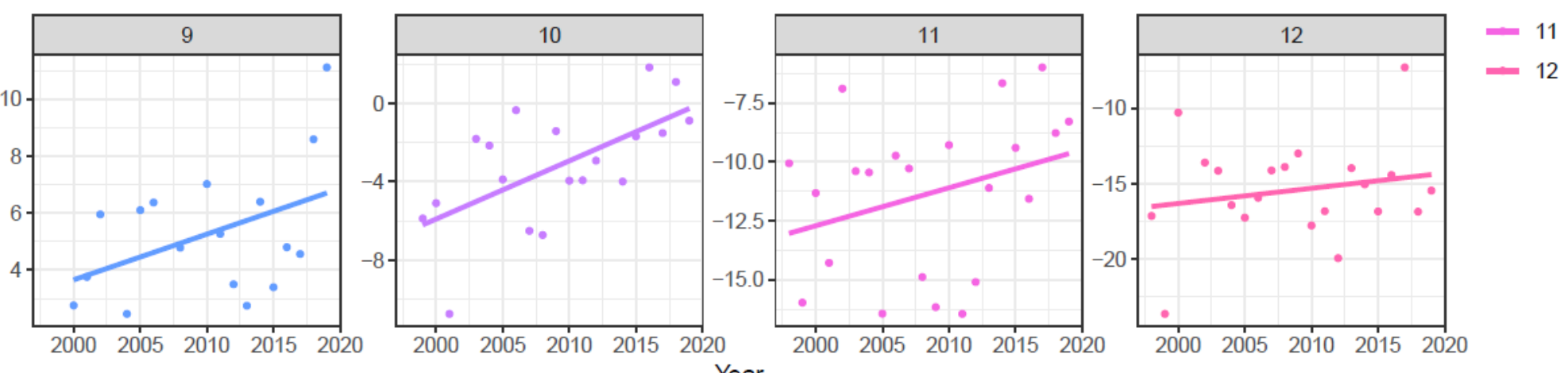

Figure A2.2 Trends in air temperature in Kivalina, Alaska, from 1998 to 2020. Points are the average of daily temperature values for each month. Lines are predicted values from linear regression models fitted to the data (see Table A2.2). Data source: NOAA National Center for Environmental Information. 
Table A2.2 Estimated slope coefficients, F statistics, p-values, and $\mathrm{R}^{2}$ values for fitted linear regression models of monthly mean air temperature versus year for Kotzebue and Kivalina. Significant regression fits $(\mathrm{p}<0.1)$ are marked with an asterisk.

\begin{tabular}{llllll}
\hline Location & Month & $\begin{array}{l}\text { Estimated } \\
\text { slope coefficient }\end{array}$ & F statistic & p-value & $\mathrm{R}^{2}$ \\
\hline Kotzebue & January & 0.183 & 1.429 & 0.245 & 0.064 \\
Kotzebue & February & 0.108 & 0.606 & 0.445 & 0.028 \\
Kotzebue & March & 0.080 & 0.370 & 0.549 & 0.017 \\
Kotzebue & April & 0.184 & 4.382 & $0.049^{*}$ & 0.173 \\
Kotzebue & May & 0.184 & 3.952 & $0.061^{*}$ & 0.165 \\
Kotzebue & June & 0.143 & 4.411 & $0.049^{*}$ & 0.188 \\
Kotzebue & July & 0.112 & 3.383 & $0.082^{*}$ & 0.151 \\
Kotzebue & August & 0.102 & 1.987 & 0.175 & 0.095 \\
Kotzebue & September & 0.077 & 1.913 & 0.183 & 0.091 \\
Kotzebue & October & 0.195 & 7.471 & $0.013^{*}$ & 0.272 \\
Kotzebue & November & 0.109 & 0.954 & 0.340 & 0.046 \\
Kotzebue & December & 0.134 & 1.318 & 0.264 & 0.062 \\
Kivalina & January & 0.186 & 1.158 & 0.297 & 0.064 \\
Kivalina & February & 0.110 & 0.443 & 0.514 & 0.024 \\
Kivalina & March & 0.213 & 1.732 & 0.205 & 0.088 \\
Kivalina & April & 0.346 & 12.860 & $0.002^{*}$ & 0.391 \\
Kivalina & May & 0.250 & 7.358 & $0.014^{*}$ & 0.279 \\
Kivalina & June & 0.146 & 2.677 & 0.121 & 0.143 \\
Kivalina & July & 0.134 & 6.109 & $0.024^{*}$ & 0.264 \\
Kivalina & August & 0.054 & 0.481 & 0.499 & 0.031 \\
Kivalina & September & 0.160 & 3.539 & $0.079^{*}$ & 0.191 \\
Kivalina & October & 0.297 & 10.580 & $0.005^{*}$ & 0.384 \\
Kivalina & November & 0.161 & 2.185 & 0.155 & 0.098 \\
Kivalina & December & 0.101 & 0.762 & 0.394 & 0.039 \\
\hline & & & & & \\
\hline
\end{tabular}




\section{Literature Cited}

Batir, J. F., M. J. Hornbach, and D. D. Blackwell. 2017. Ten years of measurements and modeling of soil temperature changes and their effects on permafrost in Northwestern Alaska. Global and Planetary Change 148:55-71.

Euskirchen, E. S., A. P. Bennett, A. L. Breen, H. Genet, M. A. Lindgren, T. A. Kurkowski, A. D. McGuire, and T. S. Rupp. 2016. Consequences of changes in vegetation and snow cover for climate feedbacks in Alaska and northwest Canada. Environmental Research Letters 11(10): p.105003.

Fang, Z., P. T. Freeman, C. B. Field, and K. J. Mach. 2018. Reduced sea ice protection period increases storm exposure in Kivalina, Alaska. Arctic Science 4(4):525-537.

Farquharson, L. M., D. H. Mann, D. K. Swanson, B. M. Jones, R. M. Buzard, and J. W. Jordan. 2018. Temporal and spatial variability in coastline response to declining sea-ice in northwest Alaska. Marine Geology 404:71-83.

Gibbs, A. E., A. G. Snyder, and B. M. Richmond. 2019. National assessment of shoreline change-Historical shoreline change along the north coast of Alaska, Icy Cape to Cape Prince of Wales: U.S. Geological Survey Open-File Report 2019-1146, 52 p., https://doi.org/10.3133/ofr20191146.

Mahoney, A. R., H. Eicken, A. G. Gaylord, and R. Gens. 2014. Landfast sea ice extent in the Chukchi and Beaufort Seas: The annual cycle and decadal variability. Cold Regions Science and Technology 103:41-56.

NOAA National Center for Environmental Information Climate Data Online database [online] URL: https://www.ncdc.noaa.gov/cdo-web/

Swanson, D. K., 2017. Trends in greenness and snow cover in Alaska's Arctic National Parks, 2000-2016. Remote Sensing 9(6):514. 
Appendix 3. Climate stressors that Kotzebue and Kivalina harvesters describe as having the greatest effect on their access to coastal subsistence resources

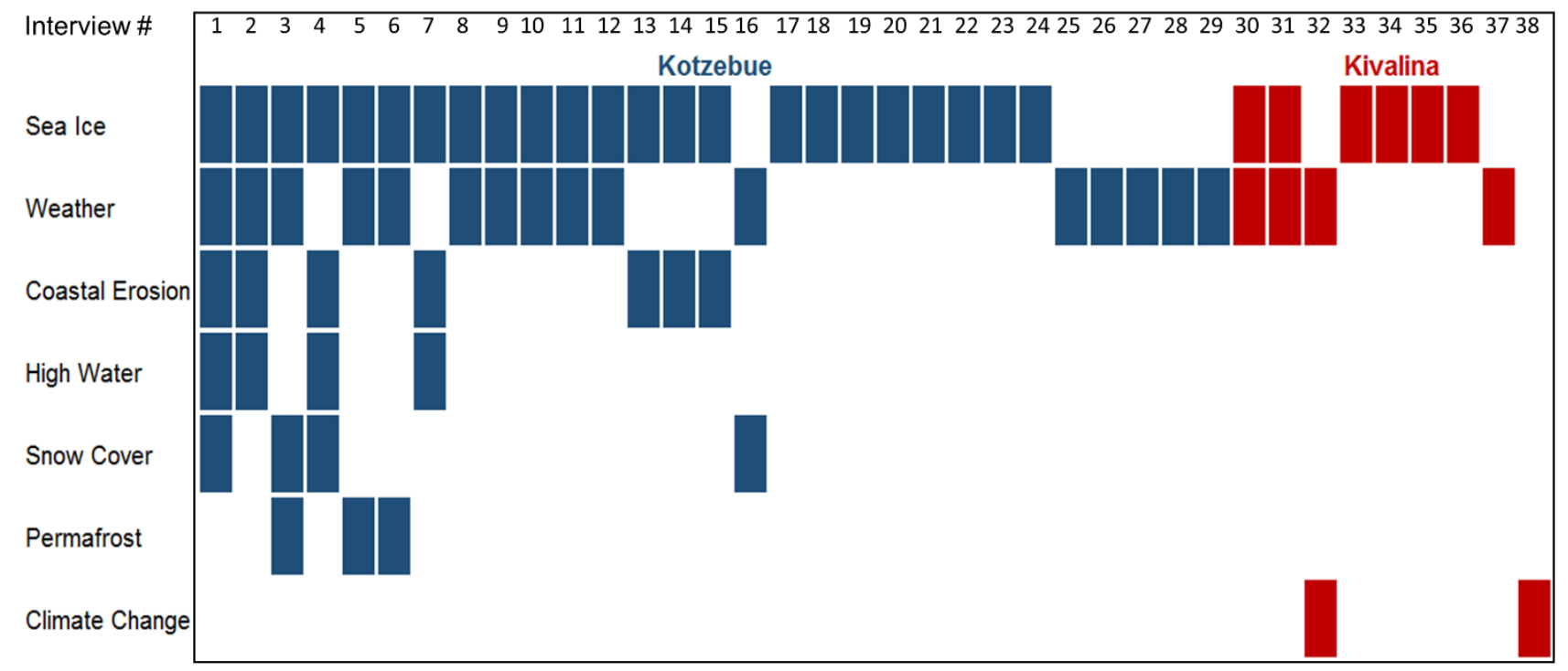

Figure A3.1 Climate stressors on y-axis (sea ice, weather, coastal erosion, high water, snow cover, permafrost and climate change) and interview respondents (x-axis) represented as blue rectangles (Kotzebue interviews) or red rectangles (Kivalina interviews). 